\title{
Estudios sobre virus transmitidos por artrópodos en Colombia
}

\author{
Hernando Groot
}

Rev. Acad. Colomb. Cienc. Ex. Fis. Nat. 1964, 12 (46): 191-217.

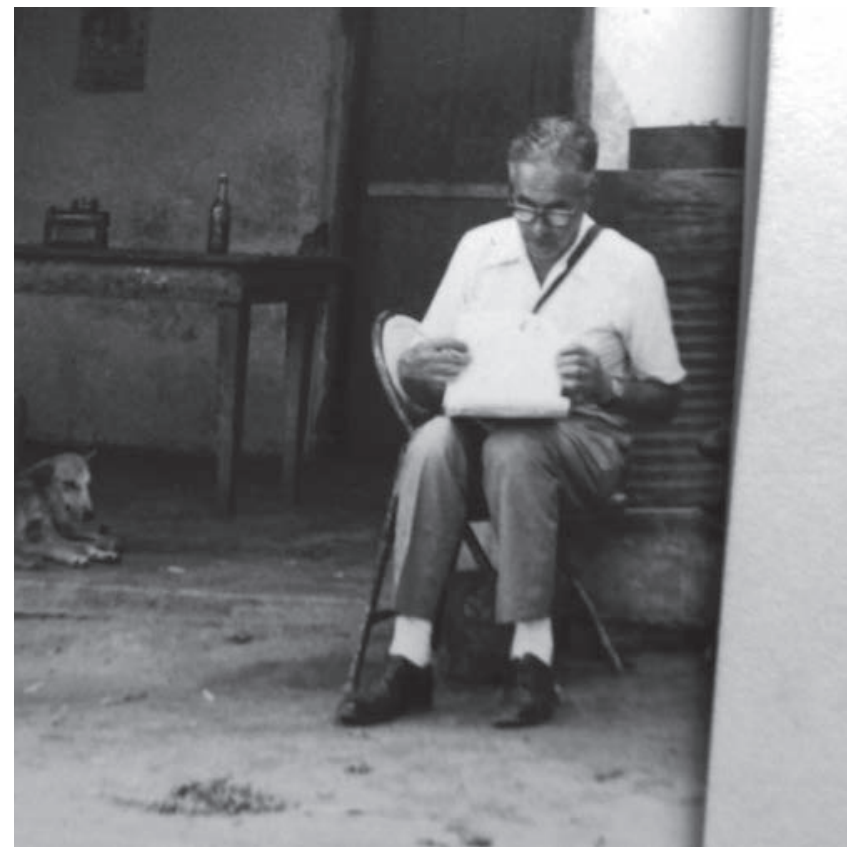

En trabajo de campo, San Vicente del Chucurí, Santander, Colombia (Archivo familiar)

\section{Hernando Groot Liévano (1917-2016)}

Médico Cirujano de la Universidad Nacional de Colombia (1939), Máster (Cum Laude) en Salud Pública de la Universidad de Harvard (1942), Diploma de Alta Gerencia en la Universidad de Los Andes (1968), Catedrático de Parasitología y Medicina Tropical en la Universidad Javeriana y en la Universidad de los Andes, Miembro del Comité de Investigaciones de la Unión Europea, Presidente del Comité Científico Asesor de la Organización Panamericana de la Salud, Director del Instituto Nacional de Salud, Vice-Rector de la Universidad de los Andes, donde fue Fundador y Decano de la Facultad de Artes y Ciencias. Miembro de la Academia Nacional de Medicina, de la cual fue Presidente y Secretario Perpetuo, Miembro de la Academia Colombiana de la Lengua, Miembro de la Academia Colombiana de Ciencias Exactas, Físicas y Naturales, de la cual fue Vicepresidente.

Información suplementaria disponible en: http://www.accefyn. org.co/sp/Groot_lievano.htm
El artículo del profesor Hernando Groot Liévano, con base en una colección de 2180 sueros (1792 humanos y 388 animales) tomados en un período de 5 años, cubrió un amplio espectro geográfico en el país representado por 4 regiones con diferentes ecosistemas. Este trabajo ejemplifica las mejores virtudes de una investigación sistemática y rigurosa, con el recurso de métodos vigentes en su momento para la caracterización de la inmunidad y en la puesta en evidencia de diferentes virus infectantes y patógenos en poblaciones humanas y animales.

La búsqueda y descripción pionera de la reactividad inmunitaria humana y animal frente a más de 15 tipos de microorganismos clasificados en esos años como Arbovirus (VEE, Mayaro, Una, Fiebre amarilla, Dengue 1, Dengue 2, Ilheus, St Louis, Bussuquara, Guaroa, Wyeomyia, EEE, Bunyamwera, Anopheles A, Anopheles B, Oropouche, Manzanilla y "Otros virus del grupo B”), incluyendo los primeros reportes de infecciones virales en el humano, como la del virus Guaroa, tanto como la puesta en evidencia de una respuesta anticuerpo específica a varios de estos virus en las poblaciones estudiadas por la reacción in vitro de las cepas virales referidas con los antisueros y controles correspondientes, configura un reporte clásico y básico para la historia de la microbiología en Colombia.

El artículo hace énfasis en la epidemiología viral y analiza las posibilidades reales de brotes infecciosos en la población. Delimita cuidadosamente las zonas de riesgo e indica la necesidad de aplicar los conceptos de salud pública al control de los artrópodos transmisores.

Se trata de un estudio sobre un tema relevante a escala nacional, escrito en el formato moderno de los artículos científicos, con una descripción juiciosa y detallada de la prevalencia de anticuerpos contra una importante serie de virus transmitidos por artrópodos en Colombia.

Alberto Gómez Gutiérrez, PhD FLS Miembro Correspondiente 


\section{ESTUDIOS SOBRE VIRUS TRANSMITIDOS POR ARTROPODOS EN COLOMBIA}

HERNANDO GROOT*

\section{INTRODUCCION}

El presente trabajo, llevado a cabo en el extinguido Instituto "Carlos Finlay" de Bogotá, principalmente tiene por objeto informar sobre los resultados de varios estudios serológicos para conocer la prevalencia de anticuerpos contra virus transmitidos por artrópodos (1) en cuatro regiones geográficas diferentes de Colombia. A estos agentes nos referiremos en forma abreviada con el término usual de "virus arbo". Los estudios, inéditos hasta ahora, comprenden 1.792 sueros humanos y 388 de origen animal, en la mayoría de los cuales se investigaron anticuerpos para diferentes virus, especialmente para fiebre amarilla, dengue, Ilheus, St. Louis, Bussuquara, Guaroa, Mayaro y encefalitis equina venezolana (VEE). En el trabajo se muestran además varias informaciones sobre aislamientos de virus, y, finalmente, como resultado de las distintas investigaciones presentadas, se describe la situación actual de los virus transmitidos por artrópodos en el país. Esta descripción está plenamente indicada al considerarse que la actividad viral, extraordinariamente marcada en algunas zonas, en ocasiones, por causa de morbilidad y mortalidad altas, impide o limita el desarrollo de nuevos territorios y de nuevas empresas agropecuarias de producción. En otros casos determina la aparición de epidemias muy serias, tal como la reciente de la Guajira, que originó pérdidas de incalculable valor.

Además del virus de fiebre amarilla, enfermedad reconocida en el país desde hace muchos años, en Colombia (2) se han encontrado otros virus arbo cuyos primeros aislamientos en el país fueron los siguientes: Wyeomyia, Anopheles A y Anopheles B por RocaGarcía en 1941 (3), VEE por Soriano-Lleras y Figueroa en 1942 (4), Guaroa, por Groot, Oya, Bernal y Barreto en 1959 (5), Ilheus, Bussuquara y Mayaro o un agente muy similar por Groot, Morales y Vidales en 1961 (6). Por otra parte, en el presente trabajo el autor presenta evidencia serológica incontrastable de la presencia en Colombia de virus del dengue, para confirmar así la impresión clínica existente desde tiempo atrás, y de los virus de la encefalitis equina del Este de los Estados Unidos, del virus de la encefalitis de St. Louis y del virus Oropouche.

\section{MATERIALES Y METODOS}

\subsection{Las zonas estudiadas}

Las encuestas serológicas en el hombre se hicieron durante el período de 1956 a 1961, en cuatro áreas geográficas y ecológicas diferentes, a saber: la zona selvática vecina a Acandí en el Golfo de Urabá, el Valle del Alto Magdalena, el Valle del Magdalena Medio y los Llanos Orientales. Los detalles sobre las fechas de san-

- Antiguo Director del Laboratorio del Instituto "Carlos Finlay", sostenido cooperativamente por el Ministerio de Salud Pública de Colombia y por la Organización Panamericana de la Salud.

Dirección actual: Universidad de los Andes, Bogotá. gría y sobre algunas características de estas áreas se han resumido en el Cuadro $\mathrm{N}^{\circ} 1$.

Golfo de Urabá. En la región de Acandí se tomaron muestras a 21 residentes de las áreas inmediatamente cercana a la población, y a una docena de indígenas que vivían en la zona denominada Guayabal, cercana de Acandí. Ambos lugares, situados a 4 metros sobre el nivel del mar, tienen una temperatura media de $27^{\circ} \mathrm{C}$ y se caracterizan por una muy abundante precipitación pluviosa. La vegetación dominante de Acandí es el bosque húmedo tropical, con zonas de desmonte. El Guayabal, exclusivamente el bosque húmedo tropical.

Valle del Alto Magdalena. En esta región hemos considerado independientemente las zonas que corresponden a la parte plana del valle, relativamente cercanas al río, y las zonas de las estribaciones montañosas vecinas, con sus numerosos valles laterales, por tener condiciones ecológicas diferentes. A las primeras, que sensu strictu corresponden al valle propiamente dicho, las hemos denominado zonas del "fondo del valle" y a las segundas zonas de "estribaciones".

Las zonas del fondo del valle, con una altura variable de 400 a 600 metros sobre el nivel del mar y con una temperatura media de $28^{\circ} \mathrm{C}$, están constituídas principalmente por praderas artificiales dedicadas a la ganadería y por cultivos de distinto tipo, en especial de algodón y de arroz. No hay allí bosque primitivo. En esta zona del fondo del valle hicimos estudios en las localidades de El Espinal, tanto en el área urbana como en el área rural, y en el leprosorio de Agua de Dios, en el área urbana.

La zona de las estribaciones comprende territorios montañosos quebrados, con estrechos valles laterales donde, además de praderas destinadas a la ganadería, hay numerosos cultivos, principalmente de café. Habitualmente la vegetación allí es más rica que en el fondo del valle, y, con frecuencia, se encuentran en aquella bosques de crecimiento secundario. La altura de esta zona es variable, habitualmente superior a los 600 metros sobre el nivel del mar. En esta área hemos estudiado la región de Villeta, tanto en el área urbana (altura 842 metros) como en la rural (altura de 600 a 1000 metros).

Valle del Magdalena Medio. Arbitrariamente hemos establecido como límite sur del Magdalena medio los $5^{\circ}$ de latitud Norte. En esta zona también hemos hecho la diferenciación entre las áreas del fondo del valle y las de las estribaciones.

En la zona del fondo del valle hemos estudiado regiones rurales de los municipios de San Vicente de Chucurí y de Barrancabermeja, caracterizadas por áreas relativamente planas o con inclinaciones suaves, y alturas variables de 150 a 500 metros sobre el nivel del mar, en las cuales la vegetación dominante es el bosque húmedo tropical, mezclado a trechos con zonas de pantanos. Hay, sinembargo, vastas regiones en las cuales el 
bosque ha sido destruído, para permitir el desarrollo de la industria ganadera.

En la zona de las estribaciones, con alturas variables de 500 a 1200 metros, hemos estudiado zonas rurales del mismo municipio de San Vicente de Chucurí y del municipio de Samaná. En estas zonas, en las que originariamente la vegetación dominante también era el bosque húmedo tropical, el desmonte con fines agrícolas ha sido casi total, lo cual determina una situación ecológica confusa y variada. Son allí numerosos los cultivos de café y, en ocasiones, los de cacao, desarrollados bajo sombra, que determinan condiciones especiales de bosque, los cuales alternan con campos de maíz o de caña o de praderas articifiales. Todavía se encuentran pequeñas áreas de bosque tropical o de bosque de crecimiento secundario que, frecuentemente, se continúan de manera insensibe, con los bosques del fondo del valle.

Llanos Orientales. En esta región hemos considerado separadamente tres zonas ecológicamente distintas. La primera es la zona de pie de monte, constituída por la parte más baja de las estribaciones de la cordillera y por las áreas planas adyacentes a estas estribaciones, que se extienden paralelamente a ellas formando una banda de terreno paralelo a la montaña, con una anchura de 30 a 40 kilómetros. En esta zona, con una temperatura media de $25^{\circ} \mathrm{C}$, una altura de 350 a 550 metros y una precipitación pluvial de 4000 milímetros anualmente, la vegetación dominante era hasta hace pocos años el bosque húmedo tropical. En la actualidad, sinembargo, los desmontes hechos para establecer especialmente empresas de ganadería, han reducido en forma considerable la extensión del bosque primitivo. En la zona de pie de monte tomamos sangre a residentes de varias localidades, desde San Martín en el sur, hasta Medina, en el norte.

La segunda zona, constituída por la zona de "llanos" propiamente dicha, está situada al este de la zona de pie de monte, con alturas habitualmente inferiores a 400 metros. Esta zona de "llanos", con precipitación pluvial menor que la de pie de monte, comprende sabanas naturales interrumpidas apenas por las angostas franjas de bosque ("matas de monte" en el lenguaje vernáculo) que se extienden a lo largo de los ríos y riachuelos y que han sido denominados frecuentemente "bosques en galería". En esta zona hemos estudiado algunos residentes de las vecindades de Puerto López y del Guaviare.

La tercera zona corresponde a las regiones orientales cubiertas por la selva húmeda tropical que se extiende ininterrumpidamente hasta el Orinoco y hasta el Amazonas. En esta área se examinaron 37 indígenas de Amanavén, en el Vichada.

Guajira. En esta península el estudio adelantado consistió esencialmente en establecer la causa de una epidemia observada a fines de 1962 . Esta zona, caracterizada por su muy escasa precipitación pluvial, está constituída por llanuras semi-desérticas con escasa vegetación xerofítica.

\subsection{Los sueros}

Las muestras de sangre se recogieron en condiciones de estricta asepsia y se refrigeraron inmediatamente después. Tan pronto como fue posibe, unas veces en el campo y otras en el laboratorio de Bogotá, se separaron los sueros y se inocularon inmediatamente a ratones lactantes por vía intracerebral, si se intentaba hacer aislamiento de virus. Si se trataba de demostrar anticuerpos, los sueros se congelaban a $-20^{\circ} \mathrm{C}$ hasta el momento de realizar las pruebas respectivas.

Las sangres humanas se obtuvieron por punción venosa. Se intentó siempre sangrar a las personas que habían vivido en las respectivas áreas durante toda su vida, o por lo menos a las personas que hacían tal declaración. Con excepción de los sueros de residentes de la zona rural de Barrancabermeja y de las zonas de pie de monte y de sabana de los Llanos Orientales, los sueros tomados corresponden a residentes de toda la vida en las respectivas áreas.

Las sangres de aves se obtuvieron por punción de la yugular, de animales vivos capturados con redes japonesas, mezclando $0.2 \mathrm{ml}$ de sangre con $0.8 \mathrm{ml}$ de solución "buffer" de bovalbumina al $5 \%$ y centrifugando luego el producto, para obtener una dilución final de suero de 1:10.

Las sangres de monos y de otros mamíferos se obtuvieron por punción cardíaca de ejemplares moribundos o recién muertos, en el curso de las capturas con tiros de rifle, utilizando proyectiles de calibre 22 .

\subsection{Virus utilizados}

Los virus o cepas de virus usados para las distintas pruebas fueron los siguientes: de fiebre amarilla la cepa neurotrópica francesa (FN) para las pruebas de neutralización y las cepas JSS y 17D para las pruebas de inhibición de hemaglutinación; la cepa Tr 1751 de Dengue 2; la cepa Laemmert de Ilheus; cepas de St. Louis y EEE, gentilmente suministradas por Rockefeller Foundation Virus Laboratories; la cepa $\operatorname{Tr} 15537$ de Mayaro aislada en Trinidad; la cepa Co. 41922 de Bussuquara, aislada en Colombia; la cepa Kubes de VEE y las cepas prototipo de Guaroa, Wyeomyia, Anopheles A y Anopheles B, aisladas en Colombia. Además se usó una cepa de virus Una aislada en Colombia, la Co. 43332, según se explica más adelante.

\subsection{Pruebas usadas}

Técnica de las pruebas NT. Las pruebas de neutralización (NT) se hicieron siguiendo la técnica de Smithburn, Kerr y Gatne (7). Con los virus Mayaro y Una se usaron ratones lactantes. Con los demás virus, ratones adultos. En las pruebas con los agentes del grupo B de Casals, la dilución final del virus se hizo en suero fresco normal de curí, para suministrar así el "factor accesorio" de suero fresco. La interpretación de los resultados se hizo según el método de Sawyer y Lloyd (8). No se aceptaron resultados positivos a menos que la dosis de virus usada hubiera sido de 50 LD50 ratón.

Interpretación de los resultados de las pruebas NT. A la luz de los conocimientos actuales, las pruebas NT son las más específicas para la demostración de anticuerpos. Por esta razón, en líneas generales, se acepta que un suero positivo para un virus indica exposición anterior del donante al mismo virus. Esta es la interpretación que hemos dado en el presente trabajo a las pruebas NT positivas con los siguientes virus: EEE, Guaroa, Wyeomyia, Oropouche, Anopheles A y Anopheles B. 
Las pruebas NT positivas con Mayaro las hemos interpretado como indicadoras de infección anterior por Mayaro o por otro virus de constitución antigénica muy similar.

En relación con los agentes del grupo B de Casals que hemos considerado en el presente estudio, (fiebre amarilla, dengue 2, Ilheus, St. Louis y Bussuquara) el problema es más complejo, porque teniendo estos virus cierta similitud antigénica entre sí, es posible que la infección con algunos de ellos determine la aparición de anticuerpos heterólogos para otros virus del mismo grupo B (9). Habitualmente, cuando encontramos un suero positivo solamente para un agente B y negativo para otros del mismo grupo, presumimos que el donante estuvo expuesto previamente a tal virus. Sinembargo, cuando se trata de positivos múltiples, puede caber la duda de si una o más de las pruebas positivas es el resultado de una reacción heteróloga. La situación no se aclara sino al considerar el cuadro inmunológico completo. El aislamiento de un virus en la localidad y el encuentro de sueros positivos solamente para un virus y negativo para los demás se consideran pruebas, incontrovertible la primera, y, muy fundada la segunda, de la actividad del mencionado agente en la región. Cuando se trata de pruebas positivas para fiebre amarilla, hemos concluído en la forma tradicional, que ellas corresponden a una infección o a una vacunación anterior.

Técnica de la prueba HI. Las pruebas de inhibición de hemoaglutinación se hicieron según la técnica de Clarke y Casals (10), utilizando el kaolín para remover los inhibidores no específicos, cuando se trataba de sueros humanos. Los sueros animales, en cambio, fueron tratados con acetona. Para las pruebas HI se hicieron diluciones seriadas de los sueros al doble, a partir de una dilución inicial al 1:10. Los antígenos se usaron a la dosis de 8 unidades. Los títulos se expresaron como el exponente de la potencia de 2 la cual, multiplicada por 5 , daba el denominador de la dilución del último tubo donde se registraba la inhibición. En esta forma si el último tubo en el cual se comprobó inhibición era aquel con la dilución $1: 10$, el título se expresa como 1 , puesto que $5 \times 2^{1}=10$; si el punto final correspondía a la dilución $1 / 20$, el título se expresa por 2 , puesto que $5 \times 2^{2}=20 ;$ y así sucesivamente, 3 corresponde a la dilución $1: 40,4$ a la dilución 1:80, etc.

Interpretación de las pruebas HI. En el análisis de las pruebas $\mathrm{HI}$ con antígeno de VEE, solamente consideramos como positivas, y por lo tanto indicadoras de exposición anterior al virus VEE a aquellos sueros que dieron reacción positiva con título 4 o superior (dilución 1:80 o más), de acuerdo con la opinión de Groot, Kerr, Sanmartín y Vidales (11), ampliamente sustentada más tarde por Sanmartín (12). De acuerdo con estos esudios, por lo menos en las áreas estudiadas en Colombia, todos los sueros con títulos 4 para VEE dieron resultado positivo en pruebas NT con el mismo agente; asimismo hemos aceptado que una prueba NT positiva para VEE significa una infección anterior por este virus en el donante del suero.

No todos los sueros colectados fueron probados con la totalidad de los antígenos en las pruebas $\mathrm{HI}$ ni con la totalidad de los virus en las pruebas NT. Para evitar repeticiones innecesarias, a medida que se presenten los resultados de las varias encuestas, se verá con qué antígenos o virus fueron probados los distintos sueros.

\section{RESULTADOS Y COMENTARIOS}

\subsection{Resultados generales}

Parece conveniente considerar primero en forma general y resumida los resultados obtenidos, de acuerdo con la región geográfica. En esta forma se obtendrá el cuadro peculiar de cada zona. Posteriormente los analizaremos de acuerdo con cada agente etiológico, para formarnos así un concepto integral de la epidemiología de cada uno de los varios virus en nuestro país.

El Cuadro № 2 muestra el resumen de los resultados de las pruebas de neutralización practicadas con los sueros humanos y siete de los virus a saber: fiebre amarilla, dengue 2, Ilheus, St. Louis, Bussuquara, Guaroa y Mayaro. En el mismo cuadro se presentan también los resultados de las pruebas $\mathrm{HI}$ con antígeno VEE.

En el Cuadro $N^{\circ} 2$ hemos incluído, para fines comparativos, algunos resultados, ya publicados en otros trabajos, a saber: los de prueba NT con fiebre amarilla, dengue 2, Ilheus, St. Louis y de pruebas HI con VEE correspondientes a residentes de toda su vida en San Vicente de Chucurí, mencionados en el trabajo de Groot, Kerr, Sanmartín y Vidales (11); los de las pruebas NT con dengue 2 en residentes de Villeta, referidos por Valencia (13) y los de las pruebas $\mathrm{HI}$ en habitantes de $\mathrm{El}$ Espinal, por Hernández (14). Estas dos últimas publicaciones corresponden a otros tantos trabajos de tesis, realizados bajo nuestra dirección, también en el Instituto "Carlos Finlay".

Golfo de Urabá. El estudio de los dos lotes de sueros recolectados en esta región, Acandí y Guayabal, nos muestra resultados relativamente similares, con excepción de aquellos relacionados con fiebre amarilla. Al analizar los resultados de cada suero en las pruebas NT, se encuentran varios positivos múltiples con los agentes del grupo B de Casals, lo cual, según se explicó arriba, dificulta la interpretación de los resultados. Sin embargo, habiéndose encontrado en esta región del Golfo de Urabá varios sueros positivos simples, solamente para Ilheus, o St. Louis o Bussuquara, nos creemos autorizados a presumir, muy fundadamente, que allí existen o han existido los mencionados virus. En cuanto a la fiebre amarilla, es interesante hacer notar que no se demostraron anticuerpos entre los indígenas de Guayabal, lo cual indica inactividad del virus en esa región selvática en los últimos 15 ó 20 años, juzgando por la edad de los indios sangrados. En cambio, en Acandí, cerca de la mitad de los casos presenta anticuerpos para el virus, por causa quizá de vacunaciones anteriores con $17 \mathrm{D}$. Es difícil interpretar los resultados de las pruebas NT para dengue, pues los casos positivos bien pueden representar infección pasada por el virus, o ser, simplemente, resultado de una reacción heteróloga. En efecto, todos los sueros positivos para dengue eran también positivos para uno o más de otros agentes del grupo B.

Las pruebas NT con virus Guaroa, cuando son positivas, las interpretamos siempre como debidas a una exposición anterior a este mismo virus. Los resultados del Golfo de Urabá muestran, pues, que este virus ha mostrado allí marcada actividad, en especial en la zona de Acandí, donde el $55 \%$ de los residentes presentaba anticuerpos.

Según se mencionó antes, hemos considerado que las pruebas HI para VEE con título 4 o más indican infec- 
ción por VEE. Sobre estas bases resulta, pues, que este virus ha mostrado actividad en el área estudiada, particularmente en los indios de Guayabal, los cuales exhiben anticuerpos en el $58 \%$ de los casos.

Entre 28 sueros estudiados, 3 dieron resultado positivo para Mayaro en pruebas NT. Este hecho indica exposición anterior a Mayaro o a otro virus antigénicamente muy cercano, tal como el virus Una.

Los sueros de esta región fueron sometidos también a pruebas NT con virus Anopheles A, con virus Anopheles $\mathrm{B}$ y con virus Wyeomyia, habiendo dado resultado negativo con estos tres agentes.

Para resumir, pues, en la región del Golfo de Urabá estudiada hay evidencia de actividad anterior de los siguientes virus: Ilheus, St. Louis, Bussuquara, Guaroa, VEE y Mayaro o un virus similar. Los casos positivos para fiebre amarilla pueden deberse a vacunaciones anteriores. $\mathrm{La}$ interpretación de los positivos para dengue es incierta.

Valle del Alto Magdalena. El cuadro inmunológico observado en las dos localidades del fondo del valle, Espinal y Agua de Dios, es muy claro. En ambos lugares hay clara evidencia de actividad anterior del virus del dengue. Los anticuerpos para este virus tienen una prevalencia del $20 \%$ en Agua de Dios, del $24 \%$ en la zona urbana de El Espinal y del $26 \%$ en la zona rural de El Espinal. En El Espinal hay además indicación de actividad anterior de VEE, lo cual concuerda con la epidemia que allí se registró en 1952, según Sanmartín, Groot y Osorno (15).

En Villeta, situada en la zona de las estribaciones, el cuadro inmunológico indica también actividad anterior del dengue, especialmente en el área urbana de la población. Allí se encontraron 2 casos positivos para VEE, pero se ignora si la infección fue adquirida en la localidad o en otro lugar.

Los casos que mostraron anticuerpos neutralizantes para fiebre amarilla entre los residentes del valle del Alto Magdalena pueden explicarse por vacunaciones anteriores, ya que desde principio del presente siglo la enfermedad no se registra en la región.

Región del Magdalena Medio. En esta región estudiamos inicialmente 1.285 muestras de sangre, tomadas a residentes de San Vicente de Chucurí. El análisis de este material, que se publicó in extenso en un trabajo anterior de Groot et al (11) mostró una alta prevalencia de anticuerpos neutralizantes para fiebre amarilla, tanto entre los habitantes de las estribaciones como entre los residentes del fondo del valle. Este hecho se interpretó como la resultante de dos factores: la presencia comprobada del virus de fiebre amarilla en la localidad y las intensas campañas de vacunación que se han adelantado en la región. En cuanto a los demás virus, se comprobó una mayor actividad de Ilheus y de VEE en la región del fondo del valle.

Los resultados que hoy presentamos por primera vez confirman la observación anterior. En efecto, de los sueros recolectados en Samaná, localizada en las estribaciones, sólo en 1 de 19 se demostraron anticuerpos neutralizantes para Ilheus y también sólo en 1 de 17 se encontraron anticuerpos HI para VEE. En cambio, en la zona rural de Barrancabermeja, se comprobó una alta prevalencia de anticuerpos para Ilheus, Bussuquara, Guaroa y Mayaro.
En la zona rural de Barrancabermeja, que corresponde al fondo del valle del río Magdalena y se continúa, hacia el este, con las zonas rurales del Municipio de San Vicente de Chucurí, examinamos 160 individuos que habían sido vacunados 6 a 8 meses antes con vacuna de $17 \mathrm{D}$ por escarificación (16). Como era de esperarse, los resultados de las pruebas NT para fiebre amarilla mostraron una alta positividad: $95 \%$. En cuanto a los demás agentes $\mathrm{B}$, el aspecto inmunológico general, detallado en el Cuadro $\mathrm{N}^{\circ}$ 3, es claramente indicativo de actividad de Bussuquara, St. Louis, Ilheus y, posiblemente, Dengue. La mayor actividad entre estos virus corresponde a Bussuquara. La prevalencia de anticuerpos para Guaroa también es muy alta: $47 \%$. Asimismo se registra una tasa elevada de anticuerpos para Mayaro: $24 \%$.

Llanos Orientales, zona de pie de monte. La totalidad de los sueros de esta zona se sometieron a pruebas $\mathrm{HI}$, con los resultados que se presentan en el Cuadro $N^{\circ}$ 4. Este cuadro muestra que la mayoría de los sueros, el $52 \%$, reaccionó con el antígeno de fiebre amarilla, cepa 17 D. De los sueros estudiados, 698 fueron probados con 4 antígenos. Los resultados, que se muestran en el Cuadro $\mathrm{N}^{\circ} 5$, son muy indicativos de que, además del virus de fiebre amarilla o de la vacuna contra esta enfermedad, en la región ha habido actividad del virus Ilheus. Estos resultados se confirman con los de las pruebas de neutralización, resumidos en el Cuadro $\mathrm{N}^{\circ} 2$. Los resultados de las pruebas HI para Ilheus y para $17 \mathrm{D}$ se analizan según la edad y el sexo en el Cuadro No 8, el cual muestra una prevalencia de anticuerpos ligeramente mayor en los hombres, pero sin ser estadísticamente significativas las diferencias. La distribución de las pruebas positivas para HI corresponde con la que se observa en regiones donde se ha vacunado contra la fiebre amarilla en forma intensa.

En el Cuadro № 7 se estudió la frecuencia de los sueros positivos cuádruples en $\mathrm{HI}$ con antígenos de 17 D; JSS, Ilheus y Dengue, para averiguar si había diferencias que indicaran mayor o menor actividad viral en las regiones del pie de monte y de la sabana y bosques. El cuadro muestra, en la zona de pie de monte, una menor actividad en el municipio de Medina. Asimismo la actividad de virus parece ser mayor en la zona de sabana y de bosques que en la de pie de monte.

Por lo que hace a otros virus, es notable la prevalencia de anticuerpos para el virus Guaroa (58\%, según se ve en Cuadro $\mathrm{N}^{9}$ 2) y la baja tasa de positividad con VEE.

Llanos Orientales, zona de sabana y de bosque. Tanto las pruebas NT, presentadas en el Cuadro $\mathrm{N}^{\circ} 2$ como las $\mathrm{HI}$, mostradas en el Cuadro $\mathrm{N}^{\circ} 6$, indican exposición anterior a los virus de fiebre amarilla (infección o vacunación) y al virus Ilheus.

Llanos Orientales, zona de bosque tropical. En el Cuadro $\mathrm{N}^{\circ} 9$ se presentan en detalle los resultados de las pruebas NT con fiebre amarilla, Ilheus, Dengue y St. Louis, hechas con los sueros de los indígenas sangrados en Amanavén, Vichada. Estos resultados muestran clara actividad pasada de fiebre amarilla y de Ilheus. Uno de los donantes dio resultado positivo con dengue, inconcluyente con Ilheus, negativo con St. Louis y negativo con fiebre amarilla. No tenemos bases suficientes para interpretar satisfactoriamente este resultado. 


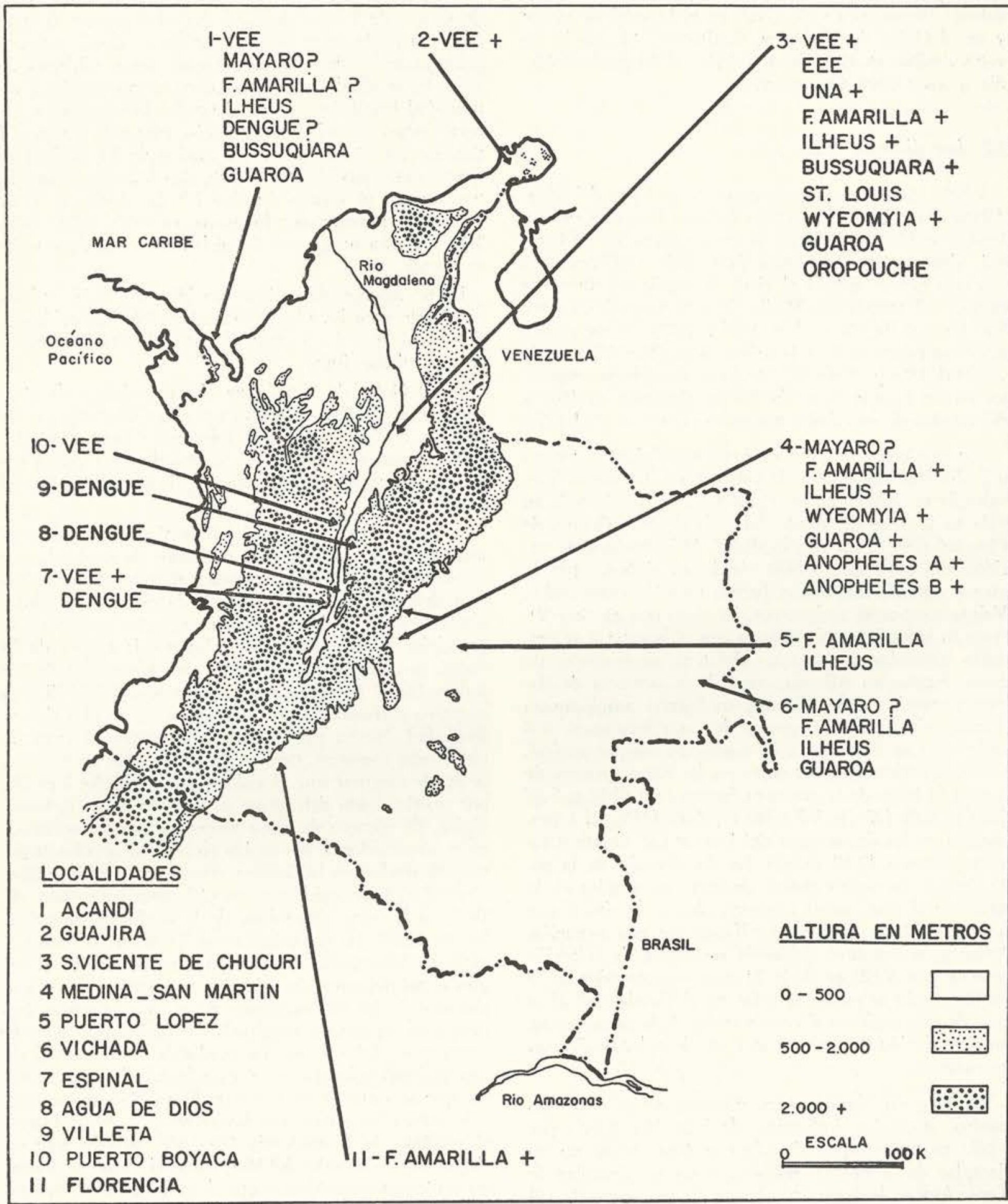

Fig. 1-Mapa de Colombia con indicación de 11 localidades donde se ha registrado actividad de virus arbo, a juzgar por las encuestas serológicas de 1956 a 1961 y por los aislamientos de virus. (Notas: El signo "+" indica que el virus fue aislado allí. El signo "?" muestra que los datos serológicos no son claros: puede tratarse de actividad pasada del virus en mención o de uno antigénicamente relacionado). 
Resumen. En la figura $N^{\circ} 1$ se presenta el resumen de la situación: actividad marcada de fiebre amarilla (o vacunación) Guaroa e Ilheus en el Golfo de Urabá, Magdalena Medio y los Llanos; VEE en el Golfo de Urabá y el Magdalena Medio; Dengue en el Alto Magdalena; Bussuquara y St. Louis en el Magdalena Medio y en el Golfo de Urabá; y, finalmente, Mayaro o un virus similar, en el Golfo de Urabá, el Magdalena Medio y los Llanos Orientales.

\subsection{Los distintos virus}

$V E E$. Este virus se encuentra en el valle del Magdalena. Su primer aislamiento de seres humanos en $\mathrm{Co}$ lombia se hizo en 1952 en la zona urbana de El Espinal, durante una epidemia (15). Más recientemente, nosotros hemos aislado el virus de residentes de zonas rurales del Magdalena Medio (Puerto Boyacá, en 1958, San Vicente de Chucurí en 1955 y 1957), de mosquitos silvestres capturados en la misma área (San Vicente de Chucurí, 1958 y 1959) (6); de ratones centinelas expuestos en un bosque cerca de Barrancabermeja en 1960 y del cerebro de un caballo muerto en Utica en 1961 (17).

Los resultados de las encuestas serológicas muestran una distribución amplia de anticuerpos. La mayor prevalencia se observó en personas que han vivido toda su vida en la zona del fondo del valle de San Vicente de Chucurí $(26 \%)$. En esta localidad, 48 individuos no nacidos allí, pero que habían vivido en el lugar por lo menos durante cinco años, fueron también examinados. Veinte mostraron anticuerpos. Es claro que en San Vicente la infección está asociada con el bosque. Las personas sangradas en esta zona vivían en cinco grupos de casas situadas en Albania, cerca de la carretera de $\mathrm{Ba}$ rrancabermeja a San Vicente, en lugares ampliamente desmontados, y en un grupo de casas localizado a 8 kilómetros de la carretera, en medio del bosque tropical. Las proporciones de inmunes en los cinco grupos de casas a lo largo de la carretera fueron 1:10 (10\%); 5:18 $(28 \%) ; 4: 15(27 \%) ; 1: 5(20 \%)$ y $4: 12(33 \%)$. La proporción en los de las casas del bosque fue significativamente mayor: 12:17 (71\%). La distribución de la población en los varios grupos de casas era similar en lo referente al sexo, edad y tiempo de residencia. En la figura $N^{\circ} 2$ se representa gráficamente esta situación. Además, se encontró evidencia serológica de infección anterior por VEE en 8 de 22 monos capturados en la región, según se puede apreciar en el Cuadro $N^{\circ} 27$, y en 2 de 16 mamíferos silvestres varios de la misma zona, un ejemplar de Bessaricyon sp y un ejemplar de Sciurus granatensis.

También en algunas aves silvestres se encontró un cuadro serológico indicativo de infección previa por VEE: en un ejemplar de Pipra erythrocephala, en un ejemplar de Manacus manacus y en un ejemplar de Xyplorhyncus lachrymosus, dentro de un grupo de 124 aves examinadas para anticuerpos HI para VEE. Estos animales hacían parte de un lote de 308 ejemplares, capturados durante 1957 y 1958 en la zona del fondo del valle de San Vicente de Chucurí. Además, el virus se ha aislado cuatro veces de mosquitos capturados en los bosques de la localidad, dos veces de "pools" de Culex spp y dos veces de "pools" compuestos por Psorophora albipes y por $P$. ferox en los cuales $P$. albipes cra la especie predominante (6).
Es interesante notar que en 100 residentes de El Espinal sangrados seis años después de la epidemia de 1952, solamente 5 eran positivos para VEE. Analizando los resultados por edad, tal como aparecen en el Cuadro $\mathrm{N}^{\circ} 10$, se ve que sólo hay un positivo entre los niños de menos de 5 años de edad. La edad precisa de este niño era la de cinco meses. Este fue el único caso positivo entre 31 niños nacidos después de la epidemia de 1952. El resultado puede explicarse como debido a inmunidad heredada, ya que el cuadro inmunológico general indica que el virus no se ha mostrado activo allí durante los últimos años. El cuadro de El Espinal es ciertamente muy distinto del de San Vicente, mostrado también en el mismo Cuadro $N^{\circ} 10$, donde el virus ha estado presente por lo menos en 1955, 1957, 1958, 1959 y 1960 a juzgar por los aislamientos de virus realizados allí.

La prevalencia de anticuerpos HI para VEE es baja en Villeta y en los Llanos Orientales. No hay evidencia de que el virus haya mostrado actividad recientemente en este último lugar.

En el Golfo de Urabá hay alta prevalencia de anticuerpos para VEE, especialmente entre los indígenas de la zona de bosque tropical húmedo. Estos resultados están de acuerdo con los de Sanmartín (18) quien encontró una actividad marcada del virus en la Costa del Pacífico.

A fines de 1962 el virus VEE ocasionó una epidemia muy seria en la Gudjira. A mediados de noviembre se registraron los primeros casos, aproximadamente un mes después de haberse iniciado la estación pluviosa, con una precipitación mayor que en años anteriores. A principios de noviembre examinamos la sangre de 18 enfermos que tenían un período de enfermedad de 1 a 5 días. De 17 de las muestras aislamos el VEE. El caso negativo correspondía a un paciente con 5 días de enfermedad. No ha sido posible aún reaislar el virus de todas estas muestras, pero, por lo menos de 14 de ellas, se puede asegurar que el aislamiento es válido, bien sea por reaislamiento del agente o por conversión inmunológica. El número de casos humanos alcanzó su máximum a mediados de noviembre en la Guajira colombiana y en diciembre en la Guajira venezolana. En diciembre terminó el brote epidémico en Colombia y en enero de 1963, en la parte venezolana de la península. Se calculan en 12.000 los casos humanos, 3.000 en Colombia y 9.000 en Venezuela, de acuerdo con Vidales (19). Según el mismo autor, la epidemia se caracterizó por una sintomatología relativamente severa y ocurrencia frecuente de signos de encefalitis. Se registraron además numerosas defunciones. La epidemia se acompañó de una serísima epizootia en el ganado caballar, con muertes que se estiman en varios millares. No se conocen con certeza las causas que favorecieron y determinaron el estallido de la epidemia. Tan sólo se sabe que en ciertas zonas del valle del Magdalena el virus se encuentra en forma enzoótica y que de allí puede extenderse a otras regiones.

Mayaro y Una. En un trabajo anterior (6) informamos sobre diez cepas de "Mayaro" aisladas de mosquitos capturados en el área del fondo del valle de San Vicente de Chucurí, durante 1958 y 1960. Estos aislamientos se hicieron así: cuatro de "pools" mixtos de $P$ sorophora ferox y $P$. albipes, cinco de $P$. ferox y una de Aedes serratus. La identificación de las cepas se hizo con base en los resultados de pruebas de neutralización 
usando suero anti-Mayaro, sin diluír, de alto título. El Dr. Max Theiler (20) estudió las cepas colombianas de "Mayaro" comprobando que, por prueba HI, se diferenciaban de las clásicas de Trinidad y que correspondían a un virus muy similar al Mayaro, el virus Una. Posteriormente, en pruebas de neutralización con los mismos sueros inmunes, pero diluídos al 1:200, comprobamos las diferencias entre las cepas colombianas inicialmente clasificadas como Mayaro y las de Mayaro aisladas en Trinidad. Un ejemplo de estas pruebas de neutralización, suficientemente demostrativo de los experimentos hechos, se presenta en el Cuadro N ${ }^{\circ} 29$. En este experimento se comparó la cepa de Mayaro de Trinidad con la cepa $N^{\circ} 43332$, aislada en Colombia.

En el Cuadro $N^{\circ} 2$ se aprecia el hecho de que los anticuerpos para Mayaro son prevalentes especialmente en el valle del Magdalena Medio y en los Llanos Orientales. El análisis por edad y sexo de los resultados de las pruebas NT con Mayaro en la zona rural de Barrancabermeja, no muestra diferencias según el sexo. En cambio, las tasas de positividad aumentan con la edad, según se demuestra en el Cuadro $N^{\circ}$ 11. La distribución de los inmunes en esta región, de acuerdo con la localización de las casas de los donantes es irregular, habiéndose encontrado la máxima positividad ( $48 \%$ de 29 personas) en los residentes dei lugar denominado Peroles, donde se hicieron los aislamientos de virus Una, a partir de mosquitos selváticos, en la forma como se explica en el Cuadro $N^{\circ} 30$.

En el momento actual es imposible definir con precisión si los sueros positivos para Mayaro representan una infección anterior con Mayaro o con Una. Fue posible probar por NT 73 sueros de Barrancabermeja, tanto con Mayaro como con Una. Los resultados mostraron 22 positivos dobles, un positivo simple para Mayaro y 8 positivos simples para Una; las 42 muestras restantes fueron negativas para ambos virus. Con los sueros del Golfo de Urabá se obtuvo un resultado similar: de 27 sueros probados con ambos virus, 3 fueron positivos para Mayaro y para Una, 11 positivos solamente para Una y 13 negativos para los dos agentes. Considerando el aislamiento repetido del virus Una en Colombia, los anteriores resultados, con excepción de un caso, el positivo solamente para Mayaro, nos inducen a pensar que los anticuerpos demostrados contra Mayaro, representan simplemente reacciones heterólogas en personas que tuvieron una exposición anterior al virus Una.

En El Espinal, 3 individuos mostraron anticuerpos para Mayaro. No se sabe si adquieron allí los anticuerpos. Es interesante notar, eso sí, que estos tres casos positivos para Mayaro no presentaban anticuerpos HI para VEE. Por lo tanto no pueden considerarse como debidos a una reacción heteróloga por este último virus.

Diez de 72 personas residentes en la zona de pie de monte de los Llanos Orientales mostraron anticuerpos para Mayaro. Es posible, pues, que este-virus, o el virus Una, u otro muy similar desde el punto de vista antigénico, haya estado presente en la región. Lo mismo puede decirse de Amanavén, donde 3 indios, sobre un total de 5, mostraron anticuerpos para Mayaro. Estos datos, sobre posibilidad de adquirir anticuerpos para este virus en la selva, están en acuerdo con el hallazgo de un cuadro inmunológico atribuíble a Mayaro (o a un virus muy similar) en 3 monos de la región del pie de monte, sobre un total de 5 , y en 4 de 12 monos capturados en el área de sabana y bosque, según se indica en el Cuadro $N^{\circ} 28$. En estos doce animales no se encontró evidencia de infección pasada con VEE. Este hallazgo contrasta con el de San Vicente, donde, de 22 monos, 6 indicaban infección previa con Mayaro, 8 con VEE, 2 con EEE y 2 con algún agente indeterminado del grupo A de Casals.

Fiebre amarilla. La fiebre amarilla selvática es enzoótica en Colombia. Cada año, desde 1933, se comprueban casos de la enfermedad, la mayoría de los cuales mediante el examen histopatológico del hígado. Desde el brote de El Socorro en 1929, no se registran casos urbanos.

En la zona de pie de monte de los Llanos Orientales, la enfermedad se observa bajo la forma de ondas epidémicas que ocurren a intervalos de 3 a 5 años y que alternan con períodos de calma, durante los cuales no se diagnostican casos de la enfermedad (21). En esta zona, el último período de actividad se registró en la parte sur; en El Doncello, cerca de Florencia, donde, después de un silencio de 34 meses, se registraron casos durante Noviembre y Diciembre de 1958 y de Julio a Diciembre de 1959.

Por otra parte, en el Valle del Magdalena, la fiebre amarilla está permanentemente presente, en una u otra parte, pero, en apariencia, no en el mismo sitio. En esta región, los casos son más frecuentes en la zona de las estribaciones. Entre los factores que determinan esta distribución, uno de los más importantes es la mayor densidad de población en las estribaciones.

En el Municipio de San Vicente de Chucurí, donde la viscerotomía ha operado continuamente desde 1935, 83 casos fatales se han diagnosticado entre 1935 y 1963. Nueve se infectaron en el fondo del valle y 64 en las estribaciones; el lugar de infección de los 10 restantes se desconoce. Los casos han ocurrido irregularmente y hay razón para presumir que, con base en estos datos cualitativos, el virus durante los 28 años en referencia, ha mostrado probablemente 9 períodos de actividad, según se puede observar en el Cuadro $\mathrm{N}^{\circ}$ 12. La información suministrada por la viscerotomía indica que el cuadro en Muzo, otro lugar de las estribaciones del Valle del Magdalena, es similar. Sinembargo el trabajo de Kerr et al (22), basado en el estudio de 2129 sueros tomados en Muzo durante 1936, cuando aún no se habían hecho vacunaciones para fiebre amarilla, no muestra periodicidad. La periodicidad hace pensar en que el virus se introduce en San Vicente a intervalos frecuentes. Es importante definir si el virus se encuentra permanentemente o sólo de modo intermitente en las estribaciones del valle del Magdalena, en lugares como Muzo y San Vicente. Si se encuentra permanentemente, debe existir un mecanismo, todavía desconocido, que produce tal persistencia. En la zona de las estribaciones de San Vicente, por ejemplo, donde la mayoría de los casos han ocurrido, los monos (con excepción del mono nocturno Aotus) son muy escasos o inexistentes. Sin embargo, en algunos tramos de bosque conectados con la selva del fondo del valle, se han visto unos pocos Cebus albifrons y Alouatta senicula. De todas maneras, su número parece ser muy escaso para explicar la persistencia del virus sobre la base del ciclo primate - mosquito solamente. Por otra parte, si el virus es introducido periódicamente, es introducido desde el área enzoótica vecina del fondo del valle, donde los monos abundan. Se puede pensar 
entonces que la invasión de las estribaciones ocurriría cuando las pequeñas y continuas epizootias errantes (que probablemente determinan la "endemicidad") llegan a la periferia del área enzoótica, se extienden a los bosques de las estribaciones y encuentran en estos condiciones favorables, todavía incompletamente conocidas. No es el objeto de este trabajo hacer especulaciones elaboradas sobre estos puntos. Sinembargo, no puede uno menos de considerar que las investigaciones futuras que se hagan al respecto deben incluír más estudios, especialmente de tipo cuantitativo, sobre los Aotus, los marsupiales y varios insectos vectores. A propósito de los últimos, la atención se ha centralizado siempre en los vectores más eficientes tales como el Haemagogus spegazzinii y su subespecie falco. En estudios recientes en la América Central, Boshell (23), Boshell y Bevier (39) y Trapido y Galindo (24) sugieren la importancia de un vector menos eficiente, el $H$. equinus, en el mantenimiento del virus de la naturaleza.

Las encuestas serológicas hechas recientemente en Colombia y las cuales presentamos en este trabajo, muestran prevalencias variables de anticuerpos para la fiebre amarilla. Los anticuerpos se deben a infección o a vacunación previa. El papel jugado por cada uno de estos dos factores varía en las distintas localidades. Por ejemplo, en el Alto Magdalena no se han registrado casos de la enfermedad durante los últimos 50 años; allí la vacunación ha sido escasa. En cambio en San Vicente y en el pie de monte de los Llanos Orientales el virus se ha mostrado activo y las campañas de vacunación han sido intensas.

Para tener un cuadro de la inmunidad producida solamente por la fiebre amarilla selvática debemos referirnos de nuevo al trabajo de Kerr y colaboradores, en Muzo (22). Este estudio mostró que el $34.1 \%$ de 2.129 personas tenía anticuerpos para fiebre amarilla. En individuos de todas las edades la proporción era de 37.8\% en los hombres y de $31.6 \%$ en las mujeres. A partir del quinto año de vida, las tasas en las mujeres eran consistentemente menores que en los hombres. En ambos sexos la positividad aumentaba rápidamente hasta la edad de 30 años, después de la cual permanecía más o menos constante $(70 \%$ en hombres y $60 \%$ en mujeres). Es de notarse que en Muzo, con frecuencia los Haemagogus llegaban hasta las casas.

Los resultados de la encuesta en los indios (no vacunados) de Amanavén mostró el aspecto familiar de una alta prevalencia de anticuerpos para fiebre amarilla (Cuadro $N^{\circ}$ 9). Resultados análogos encontramos en sangres obtenidas durante 1957 de indios de dos localidades del este de Venezuela, Santa Helena y Urimán, los cuales, para fines comparativos, se presentan en el Cuadro $\mathrm{N}^{\circ} 13$.

El estudio de las poblaciones de monos, incluyendo el aspecto de inmunidad, es un procedimiento muy importante para el estudio de la epidemiología de la fiebre amarilla, especialmente en los lugares donde la vacunación ha obscurecido el cuadro inmunológico en el hombre. Según los Cuadros Nos. 27 y 28, en los monos de San Vicente y de los Llanos Orientales se demostraron anticuerpos para el virus en proporciones variables: $26 \%$ de 42 ejemplares de San Vicente y $71 \%$ de 21 monos de los Llanos.

Durante 1957 y 1958 estudiamos también algunas aves de San Vicente de Chucurí, para investigar anticuerpos contra fiebre amarilla: de 308 ejemplares sólo uno (Dendrocolaptes certia) dio resultado positivo en NT. No estamos capacitados para interpretar correctamente este hallazgo. Nuestras observaciones en aves, esencialmente negativas, están de acuerdo con los estudios anteriores de Bugher, Boshell y Gilmore (37).

Dengue. No se han aislado virus de dengue en Colombia. Sinembargo la entidad clínica se ha diagnosticado con frecuencia en ciertos lugares tropicales, particularmente en personas recién llegadas. Tal el caso, por ejemplo, de Villeta, una población de recreo, visitada frecuentemente por los habitantes de Bogotá, ciudad esta última, donde runca se ha registrado dengue autóctono y donde no existe Aedes aegypti. Hasta hace poco tiempo era común el que el bogotano recién llegado a Villeta enfermara con una fiebre ligera que a menudo se identificaba como "chapetonada". Problemas similares se presentaban en muchas otras localidades tropicales del país, entre los recién llegados de tierras frías o de países de la zona templada. La encuesta serológica adelantada en Villeta en 1958, mostró una alta proporción $(30 \%)$ de personas con anticuerpos neutralizantes para el dengue, entre los habitantes de la zona urbana. Según se puede apreciar en el Cuadro $\mathrm{N}^{9} 14$, en este grupo de individuos, la prevalencia de anticuerpos aumenta con la edad hasta llegar al $52 \%$ en las personas de 30 y más años. Como la mayoría de los sueros positivos para dengue no mostraban anticuerpos para otros agentes del grupo $\mathrm{B}$ se concluye que los anticuerpos para dengue corresponden efectivamente a una infección antigua con el virus. Entre los habitantes de la zona rural, la positividad para dengue fue menor $(12 \%)$ y muy irregular, al considerarla según los grupos etarios. Las diferencias entre las tasas del área urbana y del área rural se explican por el hecho de que el Aedes aegypti nunca ha sido encontrado en el área rural de Villeta, mientras que sí era muy común en el área urbana hasta 1952, cuando fue erradicado, no solamente de Villeta, sino de todo el Alto Magdalena. Es muy probable que los habitantes rurales que mostraron anticuerpos para el dengue, los hubieran adquirido durante sus frecuentes visitas a la zona urbana.

Las encuestas de Agua de Dios y de El Espinal dieron resultados similares a las del área urbana de Villeta. En El Espinal no se encontraron diferencias significativas entre las tasas de la zona rural $(26 \%)$ y las de la zona urbana $(24 \%)$, según queda indicado en el Cuadro $N^{2} 15$. Este cuadro muestra además una prevalencia del dengue mucho más alta que en Villeta. En efecto, en El Espinal el 100\% de las personas examinadas de 30 y más años tiene anticuerpos para el dengue. Antes de 1953 A. aegypti era común en las áreas urbana y rural de El Espinal. Estos resultados muestran claramente que el dengue ha sido endémico en las áreas estudiadas. En el Cuadro $N^{9} 20$ se resumen los resultados de las pruebas NT en habitantes del Alto Magdalena, clasificados según la edad y el sexo. Es muy probable que la erradicación del Aedes aegypti haya cambiado rotundamente la situación mostrada en este cuadro. Debe notarse que solamente se encontró un caso NT positivo entre 39 niños de menos de 5 años de edad. Este niño fue el único que mostró anticuerpos entre 55 individuos nacidos después de las primeras fumigaciones con DDT. Los Cuadros 16, 17, 18 y 19, preparados por el autor y Hernández (19), muestran la confusa imagen de anti- 
entonces que la invasión de las estribaciones ocurriría cuando las pequeñas y continuas epizootias errantes (que probablemente determinan la "endemicidad") llegan a la periferia del área enzoótica, se extienden a los bosques de las estribaciones y encuentran en estos condiciones favorables, todavía incompletamente conocidas. No es el objeto de este trabajo hacer especulaciones elaboradas sobre estos puntos. Sinembargo, no puede uno menos de considerar que las investigaciones futuras que se hagan al respecto deben incluír más estudios, especialmente de tipo cuantitativo, sobre los Aotus, los marsupiales y varios insectos vectores. A propósito de los últimos, la atención se ha centralizado siempre en los vectores más eficientes tales como el Haemagogus spegazzinii y su subespecie falco. En estudios recientes en la América Central, Boshell (23), Boshell y Bevier (39) y Trapido y Galindo (24) sugieren la importancia de un vector menos eficiente, el $H$. equinus, en el mantenimiento del virus de la naturaleza.

Las encuestas serológicas hechas recientemente en Colombia y las cuales presentamos en este trabajo, muestran prevalencias variables de anticuerpos para la fiebre amarilla. Los anticuerpos se deben a infección o a vacunación previa. El papel jugado por cada uno de estos dos factores varía en las distintas localidades. Por ejemplo, en el Alto Magdalena no se han registrado casos de la enfermedad durante los últimos 50 años; allí la vacunación ha sido escasa. En cambio en San Vicente y en el pie de monte de los Llanos Orientales el virus se ha mostrado activo y las campañas de vacunación han sido intensas.

Para tener un cuadro de la inmunidad producida solamente por la fiebre amarilla selvática debemos referirnos de nuevo al trabajo de Kerr y colaboradores, en Muzo (22). Este estudio mostró que el $34.1 \%$ de 2.129 personas tenía anticuerpos para fiebre amarilla. En individuos de todas las edades la proporción era de $37.8 \%$ en los hombres y de $31.6 \%$ en las mujeres. A partir del quinto año de vida, las tasas en las mujeres eran consistentemente menores que en los hombres. En ambos sexos la positividad aumentaba rápidamente hasta la edad de 30 años, después de la cual permanecía más o menos constante ( $70 \%$ en hombres y $60 \%$ en mujeres). Es de notarse que en Muzo, con frecuencia los Haemagogus llegaban hasta las casas.

Los resultados de la encuesta en los indios (no vacunados) de Amanavén mostró el aspecto familiar de una alta prevalencia de anticuerpos para fiebre amarilla (Cuadro $N^{\circ}$ 9). Resultados análogos encontramos en sangres obtenidas durante 1957 de indios de dos localidades del este de Venezuela, Santa Helena y Urimán, los cuales, para fines comparativos, se presentan en el Cuadro $\mathrm{N}^{\circ} 13$.

El estudio de las poblaciones de monos, incluyendo el aspecto de inmunidad, es un procedimiento muy importante para el estudio de la epidemiología de la fiebre amarilla, especialmente en los lugares donde la vacunación ha obscurecido el cuadro inmunológico en el hombre. Según los Cuadros Nos. 27 y 28, en los monos de San Vicente y de los Llanos Orientales se demostraron anticuerpos para el virus en proporciones variables: $26 \%$ de 42 ejemplares de San Vicente y $71 \%$ de 21 monos de los Llanos.

Durante 1957 y 1958 estudiamos también algunas aves de San Vicente de Chucurí, para investigar anticuerpos contra fiebre amarilla: de 308 ejemplares sólo uno (Dendrocolaptes certia) dio resultado positivo en NT. No estamos capacitados para interpretar correctamente este hallazgo. Nuestras observaciones en aves, esencialmente negativas, están de acuerdo con los estudios anteriores de Bugher, Boshell y Gilmore (37).

Dengue. No se han aislado virus de dengue en Colombia. Sinembargo la entidad clínica se ha diagnosticado con frecuencia en ciertos lugares tropicales, particularmente en personas recién llegadas. Tal el caso, por ejemplo, de Villeta, una población de recreo, visitada frecuentemente por los habitantes de Bogotá, ciudad esta última, donde runca se ha registrado dengue autóctono y donde no existe Aedes aegypti. Hasta hace poco tiempo era común el que el bogotano recién llegado a Villeta enfermara con una fiebre ligera que a menudo se identificaba como "chapetonada". Problemas similares se presentaban en muchas otras localidades tropicales del país, entre los recién llegados de tierras frías o de países de la zona templada. La encuesta serológica adelantada en Villeta en 1958, mostró una alta proporción $(30 \%)$ de personas con anticuerpos neutralizantes para el dengue, entre los habitantes de la zona urbana. Según se puede apreciar en el Cuadro $\mathrm{N}^{\circ} 14$, en este grupo de individuos, la prevalencia de anticuerpos aumenta con la edad hasta llegar al $52 \%$ en las personas de 30 y más años. Como la mayoría de los sueros positivos para dengue no mostraban anticuerpos para otros agentes del grupo $\mathrm{B}$ se concluye que los anticuerpos para dengue corresponden efectivamente a una infección antigua con el virus. Entre los habitantes de la zona rural, la positividad para dengue fue menor $(12 \%)$ y muy irregular, al considerarla según los grupos etarios. Las diferencias entre las tasas del área urbana y del área rural se explican por el hecho de que el Aedes aegypti nunca ha sido encontrado en el área rural de Villeta, mientras que sí era muy común en el área urbana hasta 1952, cuando fue erradicado, no solamente de Villeta, sino de todo el Alto Magdalena. Es muy probable que los habitantes rurales que mostraron anticuerpos para el dengue, los hubieran adquirido durante sus frecuentes visitas a la zona urbana.

Las encuestas de Agua de Dios y de El Espinal dieron resultados similares a las del área urbana de Villeta. En El Espinal no se encontraron diferencias significativas entre las tasas de la zona rural $(26 \%)$ y las de la zona urbana $(24 \%)$, según queda indicado en el Cuadro $N^{2} 15$. Este cuadro muestra además una prevalencia del dengue mucho más alta que en Villeta. En efecto, en El Espinal el 100\% de las personas examinadas de 30 y más años tiene anticuerpos para el dengue. Antes de 1953 A. aegypti era común en las áreas urbana y rural de El Espinal. Estos resultados muestran claramente que el dengue ha sido endémico en las áreas estudiadas. En el Cuadro $N^{\circ} 20$ se resumen los resultados de las pruebas NT en habitantes del Alto Magdalena, clasificados según la edad y el sexo. Es muy probable que la erradicación del Aedes aegypti haya cambiado rotundamente la situación mostrada en este cuadro. Debe notarse que solamente se encontró un caso NT positivo entre 39 niños de menos de 5 años de edad. Este niño fue el único que mostró anticuerpos entre 55 individuos nacidos después de las primeras fumigaciones con DDT. Los Cuadros 16, 17, 18 y 19, preparados por el autor y Hernández (19), muestran la confusa imagen de anti- 


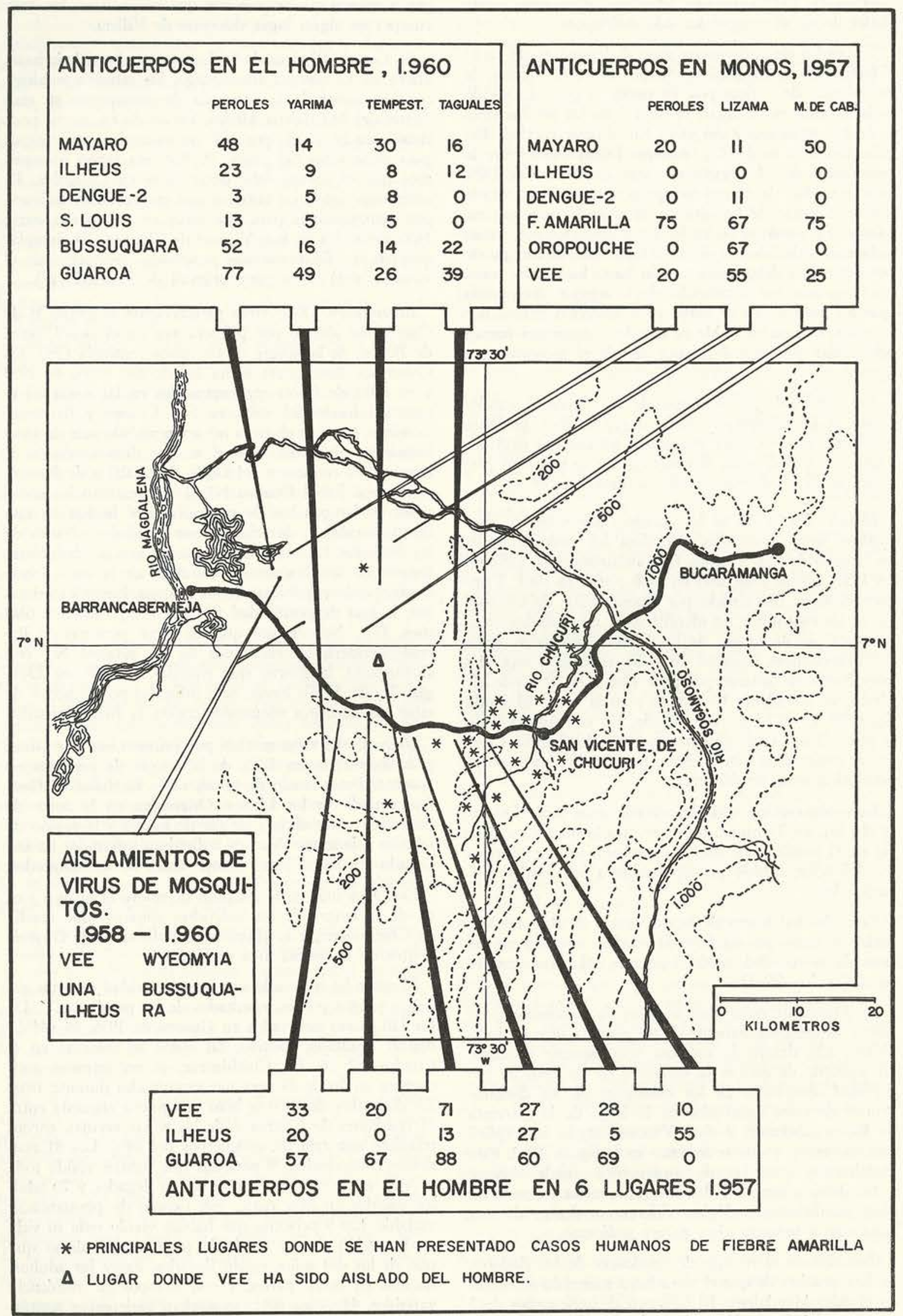

Fig. 2-Mapa de la región de San Vicente de Chucurí y de Barrancabermeja con indicación de los lugares donde se han aislado virus y donde se han hecho algunas encuestas serológicas. (Las cifras corresponden a los porcentajes de sueros positivos en las varias localidades: para ver el número de casos estudiados, véase el texto). 
de los adultos, de acuerdo con el tiempo de residencia, tal como se ha hecho en el Cuadro $N^{\circ} 23$, se advierte que la positividad aumenta con el tiempo de residencia.

El virus Guaroa no se encuentra restringido a los Llanos Orientales. En el Golfo de Urabá, más o menos la mitad de los individuos estudiados mostraba anticuerpos. En los residentes de las estribaciones de San Vicente de Chucurí la positividad fue del $10 \%$. En cambio ésta fue mucho mayor en los residentes del fondo del valle sangrados en 1957 . De 36 personas que allí habían vivido toda su vida, 22 , o sea $61 \%$ mostraban anticuerpos, y de 17, no nacidos allí pero con un tiempo de residencia superior a 5 años, $12(71 \%)$ dieron también resultado positivo. El análisis por edad y sexo de estos 53 casos se presenta en el cuadro $N^{9} 24$, que muestra un aumento de positividad a medida que aumenta la edad. Un fenómeno análogo se observa en los residentes de Barrancabermeja, zona rural, examinados en en 1960, tal como se observa en el Cuadro $N^{\circ} 25$, el cual se puede resumir diciendo que la positividad fue del $24 \%$ entre 55 menores de 15 años y del $61 \%$ entre 99 adultos. En ninguno de los dos grupos se encontraron diferencias en las tasas, relacionadas con el sexo. La marcada prevalencia de anticuerpos, que aumenta con la edad, hacen presumir que el virus Guaroa es altamente endémico en la localidad.

En esta zona rural de Barrancabermeja se sangraron 30 residentes en el lugar denominado Peroles, en la vecindad del cual se han hecho aislamientos de varios virus, pero no del virus Guaroa. La prevalencia de anticuerpos para Guaroa en estas 30 personas fue del $77 \%$, (Cuadro $N^{\circ} 30$ ); en aquellas 124 que residían lejos de Peroles, fue solamente del $40 \%$. En contraste con lo anterior, no se encontraron mayores diferencias en las tasas de positividad de los residentes, de los grupos de casas de la región de Albania, según se observa en la figura $N^{\circ} 2$.

El virus Guaroa ha sido aislado también en el Brasil por Causey (29) durante 1959, de varios casos humanos.

Whitman (30) ha demostrado que el virus Guaroa se multiplica en Aedes aegypti, Culex pipiens y Anopheles quadrimaculatus experimentalmente infectados. Recientemente, en 1961, el virus fue aislado en el Gorgas Memorial Laboratory y en la Middle America Research Unit de una mezcla de Anopheles colectados en la provincia de Bocas del Toro, Panamá (31).

A juzgar por la alta prevalencia de anticuerpos para Guaroa en los Llanos Orientales, en el fondo del valle del Magdalena Medio y en el Golfo de Urabá, se sospecha que el vector (o vectores) del virus en Colombia debe ser una especie relativamente abundante, con muchas oportunidades para picar al hombre y que se muestra activa tanto en el bosque como en regiones desmontadas.

El Cuadro No 26 resume los resultados de las pruebas NT con virus Guaroa, de acuerdo con las características de las localidades estudiadas y con la historia del virus en la región.

Virus Wyeomyia. El primer aislamiento de este virus se hizo en Colombia, a partir de ejemplares de Wyeomyia melanocephala capturados en la zona de pie de monte de los Llanos Orientales (3). Más recientemente el agente fue aislado en Trinidad de Aedes sca- pularis, Psorophora albipes, Limatus durhami y Trichoprosopon longipes (32) y en el Brasil de mosquitos sabethine y de un "pool" de Aedes sexlineatus, A. septemstriatus y $A$. serratus (33).

Cuatro cepas de Wyeomyia se aislaron en Colombia en 1960 y 1961: dos de Psorophora ferox, una de Aedes (Ochlerotatus) fulvus y una de una mezcla de Aedes (Ochlerotatus) spp recolectados en el valle del Magdalena Medio (34). Aunque no fue posible reaislar el virus del material original, por lo menos el primer aislamiento, de Aedes (Ochlerotatus), se ha considerado válido, pues se hizo cuando no se estaba usando cepa alguna de Wyeomyia en el laboratorio (34).

El virus Wyeomyia no se ha aislado hasta ahora del hombre, pero sí en este se han encontrado anticuerpos para el mismo virus. Cinco de 85 sueros del Valle del Magdalena Medio dieron resultado positivo para Wyeomyia en pruebas NT. En cambio, no se encontró resultado positivo alguno entre 134 sueros de residentes del Alto Magdalena.

$E E E$. Según se informó en un trabajo anterior, 9 sueros de residentes de San Vicente fueron probados con virus EEE por NT, con resultados negativos (11). Más recientemente Downs (35) probó con el mismo virus, por N'T también, 4 sueros de monos cazados en la zona selvática del Magdalena Medio, encontrando en dos de ellos un resultado positivo, lo cual indica actividad pasada del virus en la región.

Bunyamwera. En el mismo trabajo sobre San Vicente de Chucurí (11) informamos el hallazgo de un suero positivo por NT para Bunyamwera entre 201 de residentes de las estribaciones y de un suero positivo entre 99 habitantes del fondo del valle. La interpretación de estos resultados es muy difícil. Debe aclararse, sinembargo que estos dos sueros positivos para Bunyamwera no mostraban anticuerpos para Guaroa, de tal manera que en ellos el resultado para Bunyamwera no puede atribuírse a una infeción pasada por Guaroa. Empero, la duda sobre la epecificidad de la reacción con Bunyamwera subsiste, ya que en la región se ha aislado virus Wyeomyia, del mismo grupo antigénico.

Anopheles A. Un total de 152 sueros de residentes del Alto Magdalena y de 33 sueros del Golfo de Urabá fueron probados por NT con virus Anopheles A. Los resultados fueron negativos en todos los casos.

Anopheles B. Ciento dos sueros de habitantes del Alto Magdalena (Agua de Dios y Villeta) fueron probados con virus Anopheles B por NT, con resultados negativos en todos los casos.

Oropouche. Este virus fue aislado recientemente en Trinidad, de la sangre de una persona febril (36). No se han hecho aislamientos de este agente en Colombia. Sinembargo Downs (35) demostró anticuerpos para Oropouche en 6 de 22 monos capturados en el valle del Magdalena Medio, según se informa en el Cuadro N 27. Es interesante notar que los casos positivos sólo se encontraron en los monos capturados en la región de $\mathrm{Li}$ zama, según se puede apreciar en la figura $N^{\circ} 2$. En 12 monos de los Llanos Orientales no se encontraron anticuerpos para Oropouche.

Manzanilla. Este virus fue también aislado recientemente en Trinidad (38). Pruebas de neutralización hechas en el Trinidad Regional Virus Laboratory con vi- 
rus Manzanilla en 34 sueros de monos de Colombia, dieron resultado negativo, según se indica en los Cuadros Nos. 27 y 28.

Otros virus. A lc largo de todos estos estudios serológicos hemos encontrado proporciones variables de sueros que mostraban anticuerpos $\mathrm{HI}$ para agentes del grupo B y, sinembargo, eran completamente negativos en las pruebas NT con fiebre amarilla, Ilheus, Dengue 2, St. Louis y Bussuquara. Es de presumirse que en estos sueros los anticuerpos $\mathrm{HI}$ se deban a algún virus del grupo B diferente de los cinco agentes inmediatamente atrás nombrados, y hasta ahora no reconocido en el país.

\section{RESUMEN}

El presente trabajo, basado principalmente en nuestros estudios sobre 2180 sueros (1792 humanos y 388 de animales), conjuntamente con los resultados de algunos intentos de aislamientos de virus, permite trazar un cuadro sobre la situación actual de ciertos virus transmitidos por artrópodos en cuatro regiones diferentes de Colombia. Mayaro o Una, fiebre amarilla, Ilheus y Guaroa, han mostrado actividad en los Llanos Orientales. Aunque en el momento actual no hay evidencia de actividad corriente de virus arbo en el Alto Magdalena, el aspecto inmunológico indica que allí el dengue ha tenido marcada prevalencia, y además VEE, en la región de El Espinal. En el valle del Magdalena Medio, los siguientes virus han mostrado actividad: VEE, Mayaro o Una, fiebre amarilla, Ilheus, Bussuquara, Guaroa, Wyeomyia, Oropouche, St. Louis y EEE. En general, la actividad viral ha sido mayor allí, en la zona del valle. Se destaca el hecho de que esta intensa y variada actividad de 10 virus diferentes puede registrarse en un área de tamaño reducido, tal como la estudiada en las zonas del fondo del valle de San Vicente y Barrancabermeja. En el Golfo de Urabá los virus predominantes parecen ser Ilheus y Guaroa.

Se presentan igualmente algunos aspectos importantes de la epidemiología de los distintos virus arbo en Colombia y se relieva su importancia como agentes causales de epidemias y epizootias que dificultan el progreso de las zonas tropicales.

Se hace mención especial del virus Guaroa, probablemente el virus que mayor prevalencia tiene en las regiones tropicales colombianas, y del VEE, también ampliamente difundido en el país, con un foco enzoótico muy importante en el valle del Medio Magdalena, y agente responsable de varias epidemias y epizootias, entre otras, las que asolaron la Guajira en 1962, causando muy cuantiosas pérdidas.

\section{AGRADECIMIENTOS}

Deseo hacer constar mi sincero agradecimiento a las siguientes personas sin cuya colaboración este trabajo hubiera sido imposible: A los Doctores Augusto GastGalvis, director del antiguo Instituto "Carlos Finlay", por su asistencia y ayuda permanente y a los Doctores Enrique Prías, Hernando Vidales, Pablo Barreto, Carlos Bernal y Alberto Morales, a la señora Dora de Muschalik, y a las señoritas Clara Lesmes, Marina Sabogal y Sara Vargas, también del mismo Instituto, quienes sin excepción y con dedicación ejemplar prestaron su invaluable cooperación en distintas fases de este trabajo.
Igualmente deseo dar gracias expresivas al Dr. John Austin Kerr, de la Fundación Rockefeller, por su estímulo constante y sus valiosos consejos y a los Doctores Max Theiler, Jordi Casals y Wilbur Downs, también de la Fundación Rockefeller, por su valiosa y desinteresada colaboración.

Finalmente consigno mi agradecimiento a la Señorita Cecilia Bernal de la Universidad de los Andes, por su ayuda insustituíble en la preparación del manuscrito.

\section{REFERENCIAS BIBLIOGRAFICAS}

1. Organización Mundial de la Salud, 1961.

Virus transmitidos por Artrópodos. Informe de un Grupo de Estudio. Informe Técnico No 219, Ginebra.

2. Scott, H. H., 1939.

A history of Tropical Medicine. Edward Arnold and Co., London.

3. Roca-García, M., 1944.

"The isolation of three neurotropic viruses from forest mosquitoes in Eastern Colombia". J. Inf., Diseases, 75: 160-169.

4. Soriano-Lleras, A., and Figueroa, L., 1942. Aislamiento de un virus de caballo atacado de "peste loca", Boletín del Instituto Nacional de Higiene (Bogotá), N $\mathrm{N}^{\circ}$ 8: 4-15.

5. Groot, H., Oya, A., Bernal, C., and Barreto, P., 1959. Guaroa virus, a new agent isolated in Colombia, South America, Am. J. Trop. Med. and Hyg., 8: 604-609.

6. Groot, H., Morales, A., and Vidales, H., 1961. Virus isolations from forest mosquitoes in San Vicente de Chucurí, Colombia. Am. J. Trop. Med. \& Hyg., 10: 397-402.

7. Smithburn, K. C., Kerr, J. A., and Gatne, P. B., 1954.

Neutralizing antibodies against certain viruses in the sera of residents of India. J. Immunol, 72: 248-257.

8. Sawyer, W. A. \& Lloyd, W., 1931.

The use of mice in tests of immunity against yellow fever, J. Exp. Med., 54: 533-555.

9. Casals, J. 1963.

Relationships among arthropod-borne animal viruses determined by cross-challenge tests. Am. J. Trop. Med. and Hyg., 12: 587-596.

10. Clarke, D. H., and Casals, J., 1958.

Techniques for hemagglutination and hemagglutination-inhibition with arthropod-borne viruses. Am. J. Trop. Med. \& Hyg., 7: 561-573.

11. Groot, H., Kerr, J. A., Sanmartín, C, and Vidales, H., 1959.

Antibodies to yellow fever and other arthropod borne viruses in human residents of San Vicente de Chucurí, Santander, Colombia. Am. J. Trop. Med. \& Hyg., 8: 175-189.

12. Sanmartín, C., and Dueñas, A. 1959. Hemagglutination-inhibition and neutralization tests for the Venezuelan Equine Encephalomyelitis Virus. Am. J. Trop. Med. and Hyg, 8: 346-348.

13. Valencia, J. M., 1960. Anticuerpos para dengue y otros virus en Villeta, Cundinamarca. Universitas Medica, 5: 406.

14. Hernández, A., 1959.

Anticuerpos para el virus de la Encefalitis Equina 
Venezolana y para otros virus en El Espinal y Girardot, Colombia. Tesis, Universidad Javeriana, Bogotá.

15. Sanmartín, C., Groot. H., and Osorno, E., 1954. Human epidemic in Colombia caused by the Venezuelan Equine Encephalomyelitis Virus. Am. J. Trop. Med. and Hyg., 3: 283-293.

16. Groot, H. y Gast, A., 1964.

Observaciones sobre la vacuna de virus $17 \mathrm{D}$ para fiebre amarilla por escarificación cutánea. (Para ser publicado)

17. Barei, S., 1961.

Información personal.

18. Sanmartín, C., 1960.

Información personal.

19. Vidales, H., 1963.

Información personal.

20. Theiler, M., 1962.

Comunicación personal.

21. Gast-Galvis, A., 1958.

Incidencia de la fiebre amarilla en diferentes zonas de Colombia, Bol. Of. San. Pan., 44: 10-19.

22. Kerr, J. A., Roca-García, M., and Bugher, J. C., 1960. Naturally acquired yellow fever immunity in $\mathrm{Mu}-$ zo, Colombia. Am. J. Trop. Med. and Hyg., 9: 18-28.

23. Boshell, J., 1956.

El avance de la fiebre amarilla selvática hacia el noroeste de la América Central. Bol. Of. San. Pan., 40: 400-407.

24. Trapido, H., and Galindo, P., 1956.

The epidemiology of Yellow Fever in Middle America. Parasitological Reviews, 5, 285-323.

25. Bernal, C., 1961. Información personal.

26. Downs, W. G., Anderson, C. R., Aitken, T. H. G., and Delpeche, K. A., 1956.

Notes on the epidemiology of Ilheus virus infection in Trinidad, B. W. I. Caribbean Med. J., 18: 74-79.

27. Galindo, P., De Rodaniche, E., and Johnson, C. M., 1959.

St. Louis Encephalitis in Panama. I. Isolation of the virus from Forest Mosquitoes and Human Blood. Am. J. Trop. Med. and Hyg., 8: 557-60.
28. Gómez, G., and Causey, O. R., 1959.

Bussuquara, a new Arthropod-Borne virus. Proc. Soc. Exper. Biol. and Med., 101: 275-279.

29. Causey, O., 1960.

Comunicación personal.

30. Whitman, L., 1960. Comunicación personal.

31. Peralta, P. H. y Galindo, P., 1961.

Comunicación personal.

32. Aitken, T. H. G., 1960.

A survey of Trinidadian Arthropods for Natural Virus Infections (August, 1953 to December, 1958). Mosquito News, 20: 1-10.

33. Causey, O. R., Causey, C. E., Maroja, O. M., and Macedo, D. G., 1961.

The isolation of arthropod borne viruses in the Amazon region of Brazil including members of two hitherto undescribed serological groups, 10: 227-258.

34. Morales, A., y Vidales, H., 1962.

Distribución de mosquitos selváticos en San Vicente de Chucurí, Colombia. Lozania, N 13, págs. 3-16.

35. Downs, W. G., 1961. Comunicación personal.

36. Anderson, C. R., Spence, L., Downs, W. G., and Aitken, T. H. G., 1961.

Oropouche virus: a new human disease agent from Trinidad, West Indies. Am. J. Trop. Med. and Hyg., 10. 574-578.

37. Bugher, J. C., 1951.

The mammalian host in yellow fever. Chapter in Yellow Fever. Edit. G. K. Strode. McGraw-Hill New York, page 360.

38. Anderson, C. R., Spence, L. P., Downs, W. G., and Aitken, T. H. G., 1960.

Manzanilla Virus: a new virus isolated from the blood of a howler monkey in Trinidad, W. I. Am. J. Trop. Med. and Hyg., 9: 78-80.

39. Boshell, J., and Bevier, G. A., 1958. Yellow fever in the Lower Motagua Valley, Guatemala. Am. J. Trop. Med. and Hyg., 7: 28-35. 
CUADRO N? 1

Procedencia de 1792 sueros humanos recolectados en Colombia para investigación de anticuerpos contra virus transmitidos por artrópodos.

\begin{tabular}{|c|c|c|c|c|c|c|}
\hline Región & Tipo del área & Depto. & Localidad & $\begin{array}{l}\text { Altura } \\
\text { metros }\end{array}$ & $\begin{array}{l}\text { No de } \\
\text { sueros }\end{array}$ & $\begin{array}{l}\text { Años de } \\
\text { recolección }\end{array}$ \\
\hline Golfo de Urabá & $\begin{array}{l}\text { Bosque húmedo tropical con } \\
\text { áreas desmontadas } \\
\text { Bosque húmedo tropical }\end{array}$ & $\begin{array}{l}\text { Chocó } \\
\text { Chocó }\end{array}$ & $\begin{array}{l}\text { Acandí } \\
\text { Guayabal }\end{array}$ & $\begin{array}{l}4 \\
4\end{array}$ & $\begin{array}{l}21 \\
12 x\end{array}$ & $\begin{array}{l}1961 \\
1961\end{array}$ \\
\hline \multirow[t]{2}{*}{$\begin{array}{l}\text { Valle del } \\
\text { Alto Magdalena }\end{array}$} & $\begin{array}{l}\text { Fondo del Valle } \\
\text { (zona urbana) } \\
\text { Fondo del Valle } \\
\text { (zona rural) } \\
\text { Fondo del Valle } \\
\text { (zona urbana) }\end{array}$ & $\begin{array}{l}\text { Tolima } \\
\text { Tolima } \\
\text { Cund. }\end{array}$ & $\begin{array}{l}\text { Espinal } \\
\text { Espinal } \\
\text { Agua de Dios }\end{array}$ & $\begin{array}{l}438 \\
438 \\
552\end{array}$ & $\begin{array}{r}50 \\
50 \\
163\end{array}$ & $\begin{array}{l}1958 \\
1958 \\
1957\end{array}$ \\
\hline & $\begin{array}{l}\text { Estribaciones (zona urbana) } \\
\text { Estribaciones (zona rural) }\end{array}$ & $\begin{array}{l}\text { Cund. } \\
\text { Cund. }\end{array}$ & $\begin{array}{l}\text { Villeta } \\
\text { Villeta }\end{array}$ & $\begin{array}{l}842 \\
600-1000\end{array}$ & $\begin{array}{l}64 \\
95\end{array}$ & $\begin{array}{l}1958 \\
1958\end{array}$ \\
\hline \multirow{2}{*}{$\begin{array}{l}\text { Valle del } \\
\text { Magdalena Medio }\end{array}$} & Estribaciones & Caldas & Samaná & 800 & 40 & 1957 \\
\hline & Fondo del Valle & Santander & Barrancabermeja & 150 & 170 & 1960 \\
\hline \multirow{4}{*}{$\begin{array}{l}\text { Llanos } \\
\text { Orientales }\end{array}$} & $\begin{array}{l}\text { Pie de monte de la } \\
\text { Cordillera Oriental }\end{array}$ & $\begin{array}{l}\text { Cund. y } \\
\text { Meta }\end{array}$ & $\begin{array}{l}\text { Desde Medina } \\
\text { hasta San Martín }\end{array}$ & $\begin{array}{c}350 \\
a \\
500\end{array}$ & $\begin{array}{l}841 \times x \\
87 \\
81\end{array}$ & $\begin{array}{l}1956-57 \\
1958-59 \\
1960\end{array}$ \\
\hline & $\begin{array}{l}\text { Sabanas y bosques } \\
\text { en galería }\end{array}$ & Varios & $\begin{array}{l}\text { Pto. López } \\
\text { y otras }+\end{array}$ & $\begin{array}{l}150- \\
400\end{array}$ & 81 & $1956-57$ \\
\hline & Bosque húmedo tropical & Vichada & Amanavén & 100 & $37 x$ & 1958 \\
\hline & & & & Total & 1792 & \\
\hline
\end{tabular}

$x$ Indios habitantes de la selva.

xx Comprende 52 de Medina; 118 de Apiay, 243 de Villavicencio, 115 de Acacías, 63 de San Martín, 110 de San

Carlos de Guaroa y 140 de varias localidades.

+ Incluye 9 sueros del Guaviare y 33 de Casanare.

CUADRO N? 2

Resumen de los resultados de pruebas serológicas practicadas a personas residentes en cuatro regiones geográficas distintas de Colombia.

\begin{tabular}{|c|c|c|c|c|c|c|c|c|c|c|c|c|}
\hline Región & Area & Localidad & $\begin{array}{l}\text { Altura } \\
\text { (Mts.) }\end{array}$ & & $\begin{array}{c}\text { NT } \\
\text { Fiebre } \\
\text { Amarilla }\end{array}$ & $\begin{array}{c}\text { NT } \\
\text { Dengue }\end{array}$ & $\begin{array}{c}\text { NT } \\
\text { nheus }\end{array}$ & $\begin{array}{l}\text { NT } \\
\text { S. Louis }\end{array}$ & $\begin{array}{c}\text { NT } \\
\text { Bussq. }\end{array}$ & $\begin{array}{c}\text { NT } \\
\text { Guaroa }\end{array}$ & $\underset{\text { Mayaro }}{\mathrm{NT}}$ & $\underset{\text { VEE }}{\text { HI }}$ \\
\hline \multirow[t]{2}{*}{ Golfo de Urabá } & $\begin{array}{l}\text { Bosque y } \\
\text { desmonte }\end{array}$ & Acandí & 4 & $\begin{array}{l}\mathrm{R} . \\
\%\end{array}$ & $\begin{array}{c}10 / 21 x \\
48\end{array}$ & $\begin{array}{c}8 / 19 \\
42\end{array}$ & $\begin{array}{c}11 / 21 \\
52\end{array}$ & $\begin{array}{c}2 / 21 \\
10\end{array}$ & $\begin{array}{c}2 / 20 \\
10\end{array}$ & $\begin{array}{c}11 / 20 \\
55\end{array}$ & $\begin{array}{c}2 / 21 \\
10\end{array}$ & $\begin{array}{c}5 / 21 \\
24\end{array}$ \\
\hline & Bosque & Guayabal & 4 & $\begin{array}{l}\text { R. } \\
\% \\
\end{array}$ & $\begin{array}{c}0 / 10 \\
0\end{array}$ & $\begin{array}{c}1 / 11 \\
9\end{array}$ & $\begin{array}{l}1 / 7 \\
14 \\
\end{array}$ & $\begin{array}{c}0 / 5 \\
0\end{array}$ & $\begin{array}{l}2 / 5 \\
40 \\
\end{array}$ & $\begin{array}{c}2 / 7 \\
29 \\
\end{array}$ & $\begin{array}{r}1 / 7 \\
14\end{array}$ & $\begin{array}{c}7 / 12 \\
58\end{array}$ \\
\hline \multirow[t]{2}{*}{$\begin{array}{l}\text { Valle del } \\
\text { Alto Magdalena }\end{array}$} & $\begin{array}{l}\text { Fondo del } \\
\text { Valle }\end{array}$ & $\begin{array}{l}\text { Espinal } \\
\text { Espinal } \mathrm{xx} \\
\text { A. de Dios } \mathrm{xx}\end{array}$ & $\begin{array}{l}438 \\
438 \\
552\end{array}$ & $\begin{array}{l}\text { R. } \\
\% \\
\text { R. } \\
\% \\
\text { R. } \\
\%\end{array}$ & $\begin{array}{c}4 / 39 \\
10 \\
2 / 32 \\
6 \\
9 / 163 \\
6\end{array}$ & $\begin{array}{c}12 / 47 \\
26 \\
12 / 50 \\
24 \\
30 / 163 \\
20\end{array}$ & $\begin{array}{c}0 / 50 \\
0 \\
1 / 49 \\
2 \\
0 / 163 \\
0\end{array}$ & $\begin{array}{c}0 / 49 \\
0 \\
0 / 48 \\
0 \\
0 / 40 \\
0\end{array}$ & $\begin{array}{c}0 / 46 \\
0 \\
0 / 42 \\
0 \\
0 / 39 \\
0\end{array}$ & $\begin{array}{c}0 / 46 \\
0 \\
0 / 46 \\
0 \\
0 / 39 \\
0\end{array}$ & $\begin{array}{c}1 / 44 \\
2 \\
2 / 41 \\
5 \\
0 / 39 \\
0\end{array}$ & $\begin{array}{c}2 / 50 \\
4 \\
3 / 50 \\
6 \\
0 / 31 \\
0\end{array}$ \\
\hline & Estribaciones & $\begin{array}{l}\text { Villeta } x x \\
\text { Villeta }\end{array}$ & $\begin{array}{r}842 \\
600- \\
1000 \\
\end{array}$ & $\begin{array}{l}\text { R. } \\
\% \\
\text { R. } \\
\%\end{array}$ & $\begin{array}{c}4 / 24 \\
17 \\
4 / 55 \\
7\end{array}$ & $\begin{array}{c}19 / 64 \\
30 \\
11 / 95 \\
12\end{array}$ & $\begin{array}{c}5 / 33 \\
15 \\
1 / 56 \\
2\end{array}$ & $\begin{array}{c}0 / 25 \\
0 \\
0 / 56 \\
0\end{array}$ & $\begin{array}{c}0 / 2 \\
0 \\
0 / 22 \\
0 \\
\end{array}$ & $\begin{array}{c}0 / 29 \\
0 \\
1 / 50 \\
2 \\
\end{array}$ & $\begin{array}{c}0 / 2 \\
0 \\
0 / 22 \\
0 \\
\end{array}$ & $\begin{array}{c}1 / 27 \\
4 \\
1 / 59 \\
2 \\
\end{array}$ \\
\hline \multirow{2}{*}{$\begin{array}{l}\text { Valle del } \\
\text { Magdalena } \\
\text { Medio }\end{array}$} & Estribaciones & $\begin{array}{l}\text { Samaná } \\
\text { San Vicente }\end{array}$ & $\begin{array}{r}800- \\
1000\end{array}$ & $\begin{array}{l}\text { R. } \\
\% \\
\text { R. } \\
\%\end{array}$ & \begin{tabular}{|c|}
$26 / 40$ \\
65 \\
$342 / 442$ \\
77 \\
\end{tabular} & $\begin{array}{c}4 / 31 \\
13 \\
6 / 300 \\
2\end{array}$ & $\begin{array}{c}1 / 19 \\
5 \\
10 / 355 \\
3 \\
\end{array}$ & $\frac{-}{2 / 29}$ & $\bar{z}$ & $\begin{array}{c}- \\
\overline{6 / 60} \\
10\end{array}$ & $\frac{-}{-}$ & $\begin{array}{c}1 / 17 \\
6 \\
5 / 313 \\
2\end{array}$ \\
\hline & $\begin{array}{l}\text { Fondo del } \\
\text { Valle }\end{array}$ & $\begin{array}{l}\text { San Vicente } \\
\text { Barranca }\end{array}$ & 150 & $\begin{array}{l}\text { R. } \\
\% \\
\text { R. } \\
\%\end{array}$ & $\begin{array}{c}37 / 53 \\
70 \\
161 / 170 \\
95 \\
\end{array}$ & $\begin{array}{c}2 / 47 \\
4 \\
7 / 155 \\
5\end{array}$ & $\begin{array}{c}7 / 46 \\
15 \\
19 / 158 \\
12 \\
\end{array}$ & $\begin{array}{c}5 / 43 \\
12 \\
9 / 158 \\
6 \\
\end{array}$ & $\begin{array}{c}- \\
\overline{38 / 168} \\
23\end{array}$ & $\begin{array}{c}22 / 36 \\
61 \\
73 / 154 \\
47 \\
\end{array}$ & $\begin{array}{c}- \\
38 / 155 \\
24\end{array}$ & $\begin{array}{c}12 / 46 \\
26 \\
- \\
\end{array}$ \\
\hline \multirow{3}{*}{ Llanos Orientales } & Pie de Monte & $\begin{array}{l}\text { Medina hasta } \\
\text { San Martín }\end{array}$ & $\begin{array}{l}350- \\
500\end{array}$ & $\begin{array}{l}\mathrm{R} . \\
\%\end{array}$ & $\begin{array}{c}127 / 205 \\
62\end{array}$ & $\begin{array}{c}12 / 126 \\
10\end{array}$ & $\begin{array}{c}19 / 124 \\
15 \\
\end{array}$ & $\begin{array}{c}1 / 73 \\
1\end{array}$ & $\begin{array}{c}1 / 72 \\
1\end{array}$ & $\begin{array}{c}133 / 229 \\
58\end{array}$ & $\begin{array}{c}10 / 72 \\
14\end{array}$ & $\begin{array}{c}6 / 433 \\
1\end{array}$ \\
\hline & $\begin{array}{l}\begin{array}{l}\text { Sabana y } \\
\text { bosque }\end{array} \\
\end{array}$ & Pto. López & $\begin{array}{l}150- \\
400\end{array}$ & $\begin{array}{l}\text { R. } \\
\%\end{array}$ & $\begin{array}{c}12 / 31 \\
39 \\
\end{array}$ & $\begin{array}{c}0 / 5 \\
0\end{array}$ & $\begin{array}{c}6 / 12 \\
50\end{array}$ & $\begin{array}{c}0 / 25 \\
0\end{array}$ & - & - & - & $\begin{array}{c}1 / 57 \\
2\end{array}$ \\
\hline & Bosque & $\begin{array}{l}\text { Amanavén } \\
\text { (Vichada) }\end{array}$ & 100 & $\begin{array}{l}\text { R. } \\
\%\end{array}$ & $\begin{array}{c}19 / 37 \\
51\end{array}$ & $\begin{array}{c}3 / 33 \\
9\end{array}$ & $\begin{array}{c}16 / 34 \\
47\end{array}$ & $\begin{array}{c}0 / 27 \\
0\end{array}$ & $\begin{array}{c}0 / 5 \\
0\end{array}$ & $\begin{array}{l}2 / 6 \\
33\end{array}$ & $\begin{array}{l}3 / 5 \\
60\end{array}$ & $\begin{array}{c}1 / 36 \\
3\end{array}$ \\
\hline
\end{tabular}

x Número de positivos / número de examinados; $\%=$ porcentaje de positivos. $\quad x x$ Localidad urbana; las restantes rurales. 
CUADRO No 3

Valle del Magdalena Medio. Zona rural de Barrancabermeja. Resultado de 153 sueros probados cada uno con 4 virus del grupo B por NT.

\begin{tabular}{||c|c|c|c|c|}
\hline No & Bussuquara & St. Louis & $\begin{array}{c}\text { Dengue 2 } \\
\text { (Tr. 1751) }\end{array}$ & Ilheus \\
\hline 1 & $\mathrm{P}$ & $\mathrm{P}$ & $\mathrm{I}$ & $\mathrm{P}$ \\
1 & $\mathrm{P}$ & $\mathrm{N}$ & $\mathrm{P}$ & $\mathrm{P}$ \\
2 & $\mathrm{P}$ & $\mathrm{N}$ & $\mathrm{I}$ & $\mathrm{P}$ \\
1 & $\mathrm{P}$ & $\mathrm{N}$ & $\mathrm{P}$ & $\mathrm{N}$ \\
4 & $\mathrm{P}$ & $\mathrm{N}$ & $\mathrm{N}$ & $\mathrm{P}$ \\
3 & $\mathrm{P}$ & $\mathrm{N}$ & $\mathrm{I}$ & $\mathrm{N}$ \\
20 & $\mathrm{P}$ & $\mathrm{N}$ & $\mathrm{N}$ & $\mathrm{N}$ \\
1 & $\mathrm{I}$ & $\mathrm{P}$ & $\mathrm{P}$ & $\mathrm{P}$ \\
1 & $\mathrm{I}$ & $\mathrm{N}$ & $\mathrm{P}$ & $\mathrm{N}$ \\
6 & $\mathrm{I}$ & $\mathrm{N}$ & $\mathrm{N}$ & $\mathrm{N}$ \\
1 & $\mathrm{~N}$ & $\mathrm{P}$ & $\mathrm{P}$ & $\mathrm{N}$ \\
1 & $\mathrm{~N}$ & $\mathrm{P}$ & $\mathrm{N}$ & $\mathrm{P}$ \\
5 & $\mathrm{~N}$ & $\mathrm{P}$ & $\mathrm{N}$ & $\mathrm{N}$ \\
1 & $\mathrm{~N}$ & $\mathrm{I}$ & $\mathrm{N}$ & $\mathrm{P}$ \\
2 & $\mathrm{~N}$ & $\mathrm{~N}$ & $\mathrm{P}$ & $\mathrm{N}$ \\
1 & $\mathrm{~N}$ & $\mathrm{~N}$ & $\mathrm{I}$ & $\mathrm{P}$ \\
6 & $\mathrm{~N}$ & $\mathrm{~N}$ & $\mathrm{~N}$ & $\mathrm{P}$ \\
96 & $\mathrm{~N}$ & $\mathrm{~N}$ & $\mathrm{~N}$ & $\mathrm{~N}$ \\
\hline
\end{tabular}

$\mathrm{P}=$ Positivo. $\quad \mathrm{I}=$ Inconcluyente. $\quad \mathrm{N}=$ Negativo.

CUADRO No 4

Resumen de los resultados de pruebas HI en residentes de varias localidades de la zona de Pie de Monte de los Llanos Orientales.

\begin{tabular}{|c|c|c|c|c|c|c|c|c|c|c|}
\hline \multirow[t]{2}{*}{ Lugar } & \multirow{2}{*}{\multicolumn{2}{|c|}{$\begin{array}{c}\text { Fiebre amarilla } \\
\text { Cepa } 17 \mathrm{D} \\
\mathrm{R}^{\mathrm{x}}\end{array}$}} & \multicolumn{2}{|c|}{$\begin{array}{c}\text { Fiebre amarilla } \\
\text { Cepa JS S }\end{array}$} & \multicolumn{2}{|c|}{ Ilheus } & \multicolumn{2}{|c|}{ Dengue 2} & \multicolumn{2}{|c|}{ VEE } \\
\hline & & & $\mathrm{R}$ & $\%$ & $\mathbf{R}$ & $\%$ & $\mathbf{R}$ & $\%$ & $\mathbf{R}$ & $\%$ \\
\hline Medina & $29 / 54$ & 54 & $14 / 53$ & 26 & $2 / 52$ & 4 & $2 / 52$ & 4 & $0 / 33$ & 0 \\
\hline Apiay & $55 / 96$ & 57 & $57 / 120$ & 48 & $27 / 118$ & 23 & $28 / 118$ & 24 & $0 / 46$ & 0 \\
\hline Villavicencio & $132 / 221$ & 60 & $108 / 242$ & 45 & $33 / 242$ & 14 & $29 / 243$ & 12 & $0 / 79$ & 0 \\
\hline Acacías & $56 / 109$ & 51 & $38 / 115$ & 33 & $21 / 117$ & 18 & $18 / 115$ & 16 & $0 / 83$ & 0 \\
\hline San Martín & $19 / 41$ & 46 & $24 / 65$ & 37 & $19 / 63$ & 30 & $19 / 63$ & 30 & $0 / 28$ & 0 \\
\hline Guaroa & $20 / 57$ & 35 & $18 / 57$ & 32 & $9 / 56$ & 16 & $9 / 56$ & 16 & $3 / 43$ & 7 \\
\hline \multirow[t]{2}{*}{ Varios } & $57 / 127$ & 50 & $46 / 143$ & 32 & $22 / 142$ & 16 & $19 / 140$ & 14 & $3 / 121$ & 2 \\
\hline & $268 / 705$ & 52 & $305 / 795$ & 38 & $133 / 790$ & 17 & $124 / 787$ & 16 & $6 / 433$ & 1 \\
\hline
\end{tabular}

x $\mathrm{R}$ : No positivo / No examinado. $\quad \mathrm{xx}$ Porcentaje de positivos.

CUADRO No 5

Resultados de pruebas $\mathrm{HI}$ en sueros de personas residentes en varias localidades de la zona de Pie de Monte de los Llanos Orientales. (698 sueros probados cada uno con 4 antígenos).

\begin{tabular}{|cccc|c||}
\hline $\begin{array}{c}\text { Fiebre } \\
\text { amarilla } \\
\text { 17 D }\end{array}$ & $\begin{array}{c}\text { Fiebre } \\
\text { amarilla } \\
\text { J S S }\end{array}$ & Ilheus & Dengue 2 & Ne \\
\hline Px & $\mathrm{P}$ & $\mathrm{P}$ & $\mathrm{P}$ & $70 \times x x$ \\
$\mathrm{P}$ & $\mathrm{P}$ & $\mathrm{P}$ & $\mathrm{N} \times x$ & 10 \\
$\mathrm{P}$ & $\mathrm{P}$ & $\mathrm{N}$ & $\mathrm{P}$ & 18 \\
$\mathrm{P}$ & $\mathrm{P}$ & $\mathrm{N}$ & $\mathrm{N}$ & 163 \\
$\mathrm{P}$ & $\mathrm{N}$ & $\mathrm{N}$ & $\mathrm{N}$ & 74 \\
$\mathrm{P}$ & $\mathrm{N}$ & $\mathrm{N}$ & $\mathrm{P}$ & 3 \\
$\mathrm{P}$ & $\mathrm{N}$ & $\mathrm{P}$ & $\mathrm{P}$ & 19 \\
$\mathrm{P}$ & $\mathrm{N}$ & $\mathrm{P}$ & $\mathrm{N}$ & 11 \\
$\mathrm{~N}$ & $\mathrm{P}$ & $\mathrm{N}$ & $\mathrm{N}$ & 2 \\
$\mathrm{~N}$ & $\mathrm{~N}$ & $\mathrm{P}$ & $\mathrm{N}$ & 9 \\
$\mathrm{~N}$ & $\mathrm{~N}$ & $\mathrm{~N}$ & $\mathrm{~N}$ & 319 \\
\hline & & & Total & 698 \\
\hline
\end{tabular}

Total de positivos con antígeno $\mathrm{FA}, 17 \mathrm{D}=368(51 \%)$

Total de positivos con antígeno FA, JSS $=263(38 \%)$

Total de positivos con antígeno lilheus $=119(17 \%)$

Total de positivos con antígeno Dengue $2=113(16 \%)$

× $\mathrm{P}=$ Positivo

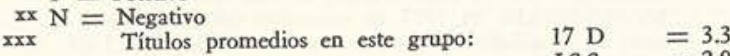

JSS $=2.9$

Ilheus $=2.9$
CUADRO N? 6

Resultados de pruebas HI en sueros de personas residentes en la zona de Sabanas y de bosques en galerías de los Llanos Orientales.

\begin{tabular}{||cccc|c||}
\hline $\begin{array}{c}\text { Fiebre } \\
\text { amarilla } \\
\text { 17 D }\end{array}$ & $\begin{array}{c}\text { Fiebre } \\
\text { amarilla } \\
\text { J S S }\end{array}$ & Tlheus & Dengue 2 & N \\
\hline Px & P & P & P & $13 \times x x$ \\
P & P & N xx & N & 14 \\
P & P & N & P & 1 \\
P & N & N & N & 3 \\
P & N & P & N & 1 \\
N & N & P & P & 1 \\
N & N & P & N & 2 \\
N & N & N & N & 34 \\
\hline & & & Total & 69 \\
\hline
\end{tabular}

Total de positivos con FA, $17 \mathrm{D}=32(46 \%)$

Total de positivos con FA, JS S $28(41 \%)$

Total de positivos con Ilheus $17(25 \%)$

Total de positivos con Dengue $215(22 \%)$

$x \mathrm{P}=$ Positivo

$\mathrm{xx} \mathrm{N}=$ Negativo

$\mathbf{x x}=$ Títulos promedios en este grupo $\quad 17 \mathrm{D}: 3.2$

Ilheus: 2.5

Dengue: 2.2 
CUADRO No 7

Resultados de pruebas $\mathrm{HI}$ en personas residentes en dos grandes zonas de los Llanos Orientales. Prevalencia de sueros positivos cuádruples probados con cuatro antígenos del Grupo B de Casals.

\begin{tabular}{|c|c|c|c|c|c|c|}
\hline \multirow{2}{*}{ Localidad } & \multicolumn{2}{|c|}{ Positivos cuádruples } & \multicolumn{4}{|c|}{ Promedio de títulos } \\
\hline & $\mathrm{R}^{\mathrm{x}}$ & $\%$ Pos. $x x$ & $17 \mathrm{D}$ & JSS & Ilheus & Dengue 2 \\
\hline $\begin{array}{l}\text { 1. ZONA DE PIE DE } \\
\text { MONTE } \\
\text { Medina } \\
\text { Apiay } \\
\text { Villavicencio } \\
\text { Acacías } \\
\text { San Martín } \\
\text { Guaroa } \\
\text { Varias }\end{array}$ & $\begin{array}{c}0 / 53 \\
13 / 86 \\
24 / 221 \\
14 / 109 \\
5 / 46 \\
5 / 57 \\
9 / 126\end{array}$ & 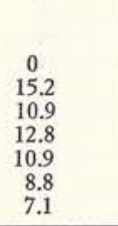 & $\begin{array}{l}3.3 \\
3.5 \\
2.9 \\
4.2 \\
1.6 \\
4.0\end{array}$ & $\begin{array}{l}\overline{2.7} \\
2.7 \\
3.8 \\
3.4 \\
1.6 \\
3.3\end{array}$ & $\begin{array}{l}3.5 \\
3.1 \\
2.3 \\
4.0 \\
1.6 \\
2.9\end{array}$ & $\begin{array}{l}\overline{3.9} \\
2.1 \\
2.4 \\
3.4 \\
2.2 \\
3.0\end{array}$ \\
\hline Total de Pie de Monte & $70 / 698$ & 10.0 & 3.3 & 2.9 & 2.9 & 2.7 \\
\hline $\begin{array}{l}\text { 2. ZONA DE SABANAS } \\
\text { Y BOSQUES }\end{array}$ & $13 / 69$ & 18.8 & 3.2 & 2.5 & 2.8 & 2.2 \\
\hline
\end{tabular}

× $\mathrm{N}$ \% de sueros positivos cuádruples / $\mathrm{N}$ \% total de sueros.

xx Porcentaje de sueros positivos con los cuatro antígenos.

\section{CUADRO NQ 8}

Resultados de pruebas HI con antígenos de Fiebre Amarilla (17D) y de Ilheus en residentes de la zona de Pie de Monte de los Llanos Orientales. Análisis por edad y sexo.

\begin{tabular}{|c|c|c|c|c|c|c|c|}
\hline \multirow{2}{*}{ Antígeno } & \multirow[t]{2}{*}{$\begin{array}{c}\text { Edad } \\
\text { (años) }\end{array}$} & \multicolumn{2}{|c|}{ Hombres } & \multicolumn{2}{|c|}{ Mujeres } & \multicolumn{2}{|c|}{ Total } \\
\hline & & $\mathbf{R}$ & $\%$ & $\mathbf{R}$ & $\%$ & $\mathbf{R}$ & $\%$ \\
\hline \multirow[t]{2}{*}{$17 \mathrm{D}$} & $\begin{array}{c}5-9 \\
10-14 \\
15-19 \\
20-29 \\
30-39 \\
40-49 \\
50+\end{array}$ & $\begin{array}{c}3 / 11 \\
7 / 26 \\
33 / 72 \\
96 / 176 \\
64 / 109 \\
23 / 37 \\
26 / 38\end{array}$ & $\begin{array}{l}27 \\
27 \\
46 \\
55 \\
59 \\
62 \\
68\end{array}$ & $\begin{array}{c}1 / 4 \\
6 / 14 \\
13 / 29 \\
22 / 50 \\
9 / 22 \\
5 / 14 \\
5 / 7 \\
\end{array}$ & $\begin{array}{l}25 \\
43 \\
45 \\
44 \\
41 \\
36 \\
71 \\
\end{array}$ & $\begin{array}{c}4 / 15 \\
13 / 40 \\
46 / 101 \\
118 / 226 \\
73 / 131 \\
28 / 51 \\
31 / 45\end{array}$ & $\begin{array}{l}27 \\
32 \\
46 \\
52 \\
56 \\
56 \\
69\end{array}$ \\
\hline & Total & $252 / 469$ & 54 & $61 / 140$ & 44 & $313 / 609$ & 51 \\
\hline \multirow[t]{2}{*}{ Ilheus } & $\begin{array}{c}5-9 \\
10-14 \\
15-19 \\
20-29 \\
30-39 \\
40-49 \\
50+\end{array}$ & $\begin{array}{c}1 / 11 \\
2 / 29 \\
11 / 83 \\
25 / 190 \\
18 / 119 \\
13 / 43 \\
18 / 40 \\
\end{array}$ & $\begin{array}{r}9 \\
7 \\
13 \\
13 \\
15 \\
30 \\
45 \\
\end{array}$ & $\begin{array}{l}0 / 4 \\
1 / 16 \\
1 / 33 \\
8 / 58 \\
4 / 23 \\
2 / 15 \\
2 / 8 \\
\end{array}$ & $\begin{array}{r}0 \\
6 \\
3 \\
14 \\
17 \\
13 \\
25 \\
\end{array}$ & $\begin{array}{c}1 / 15 \\
3 / 45 \\
12 / 116 \\
33 / 248 \\
22 / 142 \\
15 / 58 \\
20 / 48\end{array}$ & $\begin{array}{r}7 \\
7 \\
10 \\
13 \\
16 \\
24 \\
42 \\
\end{array}$ \\
\hline & Total & $88 / 515$ & 17 & $18 / 157$ & 11 & $106 / 672$ & 16 \\
\hline
\end{tabular}

CUADRO N? 9

Resultados de pruebas de neutralización en sueros de 37 indios de Amanavén.

\begin{tabular}{|c|c|c|c|c|c|}
\hline Fiebre & amarilla & Ilheus & Dengue 2 & St. Louis & No \\
\hline & P & P & $\mathbf{P}$ & - & 1 \\
\hline & P & P & I & $\mathrm{N}$ & 3 \\
\hline & P & $\mathrm{P}$ & $\mathrm{N}$ & $\mathrm{N}$ & 4 \\
\hline & P & P & $\mathrm{N}$ & - & 1 \\
\hline & $\mathrm{P}$ & I & I & $\mathrm{N}$ & 3 \\
\hline & $\mathrm{P}$ & I & $\mathbf{N}$ & $\mathrm{N}$ & 3 \\
\hline & P & $\hat{N}$ & $\mathrm{~N}$ & $\mathrm{~N}$ & 1 \\
\hline & $\mathrm{P}$ & - & - & - & 2 \\
\hline & $\mathrm{P}$ & $\mathrm{N}$ & $P$ & $\mathrm{~N}$ & 1 \\
\hline & I & I & $\mathbf{N}$ & $\mathrm{N}$ & 1 \\
\hline & $\mathrm{N}$ & $\mathrm{p}$ & $\mathrm{N}$ & $\mathrm{N}$ & 1 \\
\hline & $\mathrm{N}$ & P & $\mathrm{N}$ & - & 2 \\
\hline & $\mathrm{N}$ & $\mathrm{P}$ & I & $\mathrm{N}$ & 1 \\
\hline & $\mathrm{N}$ & P & - & $\mathrm{N}$ & 1 \\
\hline & $\mathrm{N}$ & P & $\mathrm{N}$ & $\mathrm{N}$ & 1 \\
\hline & $\mathrm{N}$ & $\mathrm{P}$ & - & - & 1 \\
\hline & $\mathrm{N}$ & I & P & $\mathrm{N}$ & 1 \\
\hline & $\mathrm{N}$ & - & - & - & 1 \\
\hline & $\mathrm{N}$ & $\mathrm{N}$ & $\mathrm{N}$ & - & 1 \\
\hline & $\mathrm{N}$ & $\mathrm{N}$ & $\mathrm{N}$ & $\mathrm{N}$ & 7 \\
\hline & & & & Total & 37 \\
\hline
\end{tabular}

$\mathrm{P}=$ Positivo
CUADRO Nㅇ 10

Virus VEE. Resultados de pruebas $\mathrm{HI}$ en sueros humanos de residentes en dos localidades de Colombia.

\begin{tabular}{|c|c|c|c|c|}
\hline \multirow{2}{*}{$\begin{array}{c}\text { Edad } \\
\text { (Años) }\end{array}$} & \multicolumn{2}{|c|}{ Espinal 1) } & \multicolumn{2}{|c|}{ San Vicente 2) } \\
\hline & Relación 3) & $\%$ Pos. & Relación & $\%$ Pos. \\
\hline$<1$ & $1 / 8 x$ & 13 & - & - \\
\hline $1-4$ & $0 / 15$ & 0 & - & - \\
\hline $5-9$ & $1 / 22$ & 7 & $3 / 17$ & 18 \\
\hline $10-14$ & $1 / 19$ & 5 & $12 / 35$ & 34 \\
\hline $15-19$ & $1 / 17$ & 6 & $2 / 7$ & 28 \\
\hline $20-29$ & $1 / 13$ & 8 & $2 / 5$ & 40 \\
\hline $30+$ & $0 / 6$ & 0 & $13 / 30$ & 43 \\
\hline Total & $5 / 100$ & 5 & $32 / 94$ & 34 \\
\hline
\end{tabular}

1) Sueros obtenidos 6 años después de una epidemia.

2) Sueros obtenidos en 1957 de residentes del fondo del valle. El virus se ha aislado en la región durante 1955, 1957, 1958, 1959 y 1960.

3) Número de sueros positivos con títulos de 4 o más / número

total de sueros probados.
$\times$ Edad del caso positivo: 5 meses. Este resultado podría explicarse por inmunidad heredada de la madre. 
CUADRO N? 11

Valle del Magdalena Medio. Zona rural de Barrancabermeja. Resultado de pruebas de neutralización con Virus Mayaro en 155 personas residentes del fondo del valle, analizados por edad y sexo.

\begin{tabular}{|c|c|c|c|c|c|c|}
\hline \multirow{2}{*}{$\begin{array}{c}\text { Edad } \\
\text { (Años) }\end{array}$} & \multicolumn{2}{|c|}{ Hombres } & \multicolumn{2}{|c|}{ Mujeres } & \multicolumn{2}{|c|}{ Total } \\
\hline & $\mathrm{R}^{\mathrm{x}}$ & $\%$ & & $\%$ & $\mathrm{R}$ & $\%$ \\
\hline $0-4$ & $0 / 11$ & 0 & $0 / 8$ & 0 & $0 / 19$ & 0 \\
\hline $5-9$ & $1 / 9$ & 11 & $3 / 10$ & 30 & $4 / 19$ & 21 \\
\hline $10-14$ & $2 / 10$ & 20 & $1 / 9$ & 11 & $3 / 19$ & 16 \\
\hline $15-19$ & $2 / 9$ & 22 & $2 / 10$ & 20 & $4 / 19$ & 21 \\
\hline $20-29$ & $1 / 9$ & 11 & $2 / 12$ & 17 & $3 / 21$ & 14 \\
\hline $30-39$ & $4 / 10$ & 40 & $3 / 10$ & 30 & $7 / 20$ & 35 \\
\hline $40-49$ & $5 / 10$ & 50 & $2 / 9$ & 22 & $7 / 19$ & 37 \\
\hline $50+$ & $4 / 9$ & 45 & $6 / 10$ & 60 & $10 / 59$ & 53 \\
\hline Total & $19 / 77$ & 25 & $19 / 78$ & 24 & $38 / 155$ & 25 \\
\hline
\end{tabular}

x Relación: No positivo / № examinado.
CUADRO No 13

Resultados de pruebas de neutralización con tres virus del grupo B practicadas a indios residentes en dos regiones de Venezuela Orienta! Urimán y Santa Helena, (1957).

\begin{tabular}{||ccc|c|c||}
\hline \multicolumn{3}{|c|}{ Virus } & & \multicolumn{2}{|c||}{ Localidades } \\
\cline { 5 - 5 } Fiebre & Theus & Dengue 2 & $\begin{array}{c}\text { Urimán } \\
\text { No de casos }\end{array}$ & $\begin{array}{c}\text { Santa Helena } \\
\text { No de casos }\end{array}$ \\
\cline { 5 - 5 } P & P & P & 5 & 3 \\
P & P & N & 4 & 3 \\
P & P & I & 0 & 1 \\
P & I & P & 1 & 0 \\
P & I & I & 3 & 0 \\
P & I & N & 2 & 0 \\
P & N & I & 0 & 1 \\
P & N & N & 7 & 1 \\
N & I & P & 1 & 0 \\
N & N & P & 0 & 1 \\
N & P & I & 1 & 1 \\
N & P & N & 2 & 12 \\
N & I & I & 0 & 1 \\
N & I & N & 0 & 3 \\
N & N & N & 2 & 14 \\
\hline & & Total & 28 & 41 \\
\hline
\end{tabular}

$$
\mathrm{P}=\text { Positivo } \quad \mathrm{I}=\text { Inconcluyente } \quad \mathrm{N}=\text { Negativo }
$$

CUADRO № 12

Probables períodos de actividad del virus de fiebre amarilla en la región de San Vicente de Chucurí.

\begin{tabular}{||l|c|c|c||}
\hline Período de actividad & $\begin{array}{c}\text { Número } \\
\text { de muertes } \\
\text { por fiebre } \\
\text { amarilla }\end{array}$ & $\begin{array}{c}\text { Duración } \\
\text { del } \\
\text { período de } \\
\text { actividad } \\
\text { en meses }\end{array}$ & $\begin{array}{c}\text { Duración } \\
\text { del período } \\
\text { subsiguiente } \\
\text { de inactividad } \\
\text { aparente }\end{array}$ \\
\hline Julio 1936-Febrero 1937 & 16 & 8 & 41 \\
Julio 1940-Dic. 1941 & 15 & 18 & 24 \\
Enero 1944-Octubre 1944 & 2 & 10 & 19 \\
Junio 1946-Febrero 1947 & 15 & 9 & 20 \\
Noviembre 1948 & 1 & 1 & 25 \\
Enero 1951-Enero 1952 & 12 & 13 & 30 \\
Agosto 1954-Julio 1955 & 14 & 12 & 25 \\
Septiembre 1957-Dic. 1958 & 6 & 16 & 30 \\
Julio 1961-Septiembre 1962 & 2 & 15 & $18 x$ \\
\hline \hline
\end{tabular}

x Comprobadas por el estudio microscópico del hígado. xx Datos hasta febrero 1964.

CUADRO N ${ }^{\circ} 14$

Villeta. Virus Dengue 2. Resultados de pruebas de neutralización en sueros de residentes de toda la vida.

\begin{tabular}{|c|cc|cc||}
\hline \multirow{2}{*}{ Edad } & \multicolumn{2}{|c|}{ Zona rural } & \multicolumn{2}{|c|}{ Zona urbana } \\
& \multicolumn{2}{|c|}{$\mathbf{R}^{x}$} & $\%$ & \multicolumn{2}{|c|}{$\mathrm{R}$} & $\%$ \\
\cline { 2 - 5 } $1-4$ & $0 / 3$ & 0 & $1 / 8$ & 13 \\
$5-9$ & $2 / 14$ & 14 & $1 / 13$ & 8 \\
$10-14$ & $0 / 13$ & 0 & $0 / 7$ & 0 \\
$15-19$ & $2 / 14$ & 14 & $3 / 8$ & 38 \\
$20-29$ & $3 / 15$ & 20 & $3 / 7$ & 43 \\
$30+$ & $4 / 36$ & 11 & $11 / 21$ & 52 \\
\hline Total & $11 / 95$ & 12 & $19 / 64$ & 30 \\
\hline
\end{tabular}

× Relación: número positivo / número examinado.

CUADRO No 15

Espinal. Virus Dengue 2. Resultados de pruebas de neutralización en sueros de residentes de toda la vida.

\begin{tabular}{|c|c|c|c|c|}
\hline Edad & \multicolumn{2}{|c|}{ Zona rural } & $\begin{array}{l}\text { Zona } \\
\text { R }\end{array}$ & na \\
\hline $\begin{array}{c}<1 \\
1-4 \\
5-9 \\
10-14 \\
15-19 \\
20-29 \\
30+\end{array}$ & $\begin{array}{l}0 / 5 \\
0 / 8 \\
0 / 9 \\
5 / 9 \\
3 / 10 \\
3 / 5 \\
1 / 1\end{array}$ & $\begin{array}{r}0 \\
0 \\
0 \\
56 \\
30 \\
60 \\
100\end{array}$ & $\begin{array}{l}0 / 3 \\
0 / 7 \\
1 / 11 \\
0 / 10 \\
3 / 7 \\
4 / 8 \\
4 / 4\end{array}$ & $\begin{array}{r}0 \\
0 \\
9 \\
0 \\
43 \\
50 \\
100\end{array}$ \\
\hline Total & $12 / 47$ & 26 & $12 / 50$ & 24 \\
\hline
\end{tabular}

x Relación: número positivo / número examinado. 
CUADRO NQ 16

Análisis por edad de los resultados de pruebas HI con 5 antígenos del grupo B practicadas con sueros de residentes de toda la vida en Villeta. Zona Urbana.

\begin{tabular}{|c|c|c|c|c|c|c|c|c|c|c|c|c|c|c|c|c|}
\hline \multirow{4}{*}{$\begin{array}{c}\begin{array}{c}\text { Edad en } \\
\text { años }\end{array} \\
1.4\end{array}$} & \multirow{4}{*}{$\begin{array}{c}\begin{array}{c}\mathrm{N}^{\circ} \mathrm{de} \\
\text { personas } \\
\text { examinadas }\end{array} \\
8\end{array}$} & \multicolumn{6}{|c|}{ FIEBRE AMARILLA } & \multirow{2}{*}{\multicolumn{3}{|c|}{$\begin{array}{c}\text { ILHEUS } \\
\text { Cepa Laemmert }\end{array}$}} & \multirow{2}{*}{\multicolumn{3}{|c|}{$\frac{\text { DENGUE II }}{\text { Cepa Tr. } 1751}$}} & \multirow{2}{*}{\multicolumn{3}{|c|}{ ST. LOUIS }} \\
\hline & & \multicolumn{3}{|c|}{ Cepa $17 \mathrm{D}$} & \multicolumn{3}{|c|}{ Cepa JSS } & & & & & & & & & \\
\hline & & $\mathrm{N}^{9} \mathrm{P}$ & $\% \mathrm{P}+$ & om. $x x$ & No & $\% \mathrm{P}$ & Prom. & No 1 & $\% \mathrm{P}$. & Prom. & No 1 & $\% \mathrm{P}$. & rom. & NoP. & $\% \mathrm{P}$. & rom. \\
\hline & & 3 & 38 & 2.0 & 1 & 13 & 1.0 & 0 & 0 & - & 0 & 0 & - & 1 & 13 & 2 \\
\hline $5-9$ & 13 & 2 & 15 & 1.5 & 2 & 15 & 1.0 & 2 & 15 & 3.5 & 1 & 8 & 3.0 & 1 & 8 & 5.0 \\
\hline $10-14$ & 7 & 0 & 一 & 一 & 1 & 14 & 3.0 & 2 & 29 & 3.0 & 1 & 14 & 5.0 & 1 & 14 & 6.0 \\
\hline $15-19$ & 8 & 3 & 38 & 3.3 & 3 & 38 & 2.3 & 3 & 38 & 4.7 & 3 & 38 & 3.7 & 3 & 38 & 4.0 \\
\hline $20-29$ & 7 & 2 & 29 & 2.0 & 2 & 29 & 1.0 & 2 & 29 & 3.5 & 3 & 43 & 2.3 & 2 & 29 & 3.5 \\
\hline $30+$ & 21 & 5 & 24 & 4.8 & 5 & 24 & 4.8 & 10 & 48 & 4.7 & 9 & 43 & 3.9 & 10 & 48 & 5.1 \\
\hline Total & 64 & 15 & 23 & 3.1 & 14 & 22 & 2.8 & 19 & 30 & 4.3 & 17 & 27 & 3.6 & 18 & 28 & 4.6 \\
\hline
\end{tabular}

$x$ No de positivos $\quad+\%$ de positivos $\quad x x$ Promedio de títulos

CUADRO No 17

Análisis por edad de los resultados de pruebas HI con 5 antígenos del grupo B practicadas con sueros de residentes de toda la vida en El Espinal. Zona Urbana.

\begin{tabular}{|c|c|c|c|c|c|c|c|c|c|c|c|c|c|c|c|c|}
\hline \multirow{3}{*}{$\begin{array}{c}\text { Edad en } \\
\text { años }\end{array}$} & \multirow{3}{*}{$\begin{array}{c}\mathrm{N}^{\circ} \mathrm{de} \\
\text { personas } \\
\text { examinadas }\end{array}$} & \multicolumn{6}{|c|}{ FIEBRE AMARILLA } & \multirow{2}{*}{\multicolumn{3}{|c|}{$\begin{array}{c}\text { ILHEUS } \\
\text { Cepa Laemmert }\end{array}$}} & \multirow{2}{*}{\multicolumn{3}{|c|}{$\begin{array}{c}\text { DENGUE II } \\
\text { Cepa Tr. } 1751\end{array}$}} & \multirow{2}{*}{\multicolumn{3}{|c|}{ ST. LOUIS }} \\
\hline & & \multicolumn{3}{|c|}{ Cepa $17 \mathrm{D}$} & \multicolumn{3}{|c|}{ Cepa JSS } & & & & & & & & & \\
\hline & & NoP & $\% \mathrm{P}+$ & rom.xx & NoP. & $\% \mathrm{P}$ & Prom. & NoP & $\% \mathrm{P}$. & Prom. & NoP. & $\% \mathrm{P}$. & Prom. & NoP. & $\% \mathrm{P}$. & Prom. \\
\hline$<1$ & 3 & 0 & 0 & & 0 & 0 & 0 & 2 & 7 & 1.5 & 0 & 0 & 0 & 2 & 67 & 2.8 \\
\hline $1-4$ & 7 & 0 & 0 & 0 & 0 & 0 & 0 & 1 & 14 & 2 & 0 & 0 & 0 & 1 & 14 & 2 \\
\hline $5-9$ & 11 & 1 & 9 & 1 & 1 & 9 & 0.5 & 4 & 36 & 2.5 & 2 & 18 & 2.0 & 6 & 55 & 2.6 \\
\hline $10-14$ & 10 & 5 & 5 & 2 & 4 & 40 & 1.7 & 9 & 9 & 3.2 & 6 & 6 & 1.8 & 10 & 100 & 3.9 \\
\hline $15-19$ & 7 & 6 & 86 & 3.8 & 6 & 86 & 3.2 & 6 & 86 & 3.5 & 6 & 86 & 3.5 & 6 & 86 & 6.0 \\
\hline $20-29$ & 8 & 6 & 75 & 1.6 & 6 & 75 & 2.3 & 5 & 63 & 1 & 5 & 63 & 2.2 & 5 & 63 & 4.4 \\
\hline $30+$ & 4 & 4 & 100 & 6.6 & 4 & 100 & 3.7 & 4 & 100 & 8.7 & 4 & 100 & 6.7 & 4 & 100 & 6.3 \\
\hline Total & 50 & 22 & 44 & 3.1 & 21 & 42 & 2.7 & 31 & 62 & 4.7 & 23 & 46 & 3.4 & 34 & 68 & 4.3 \\
\hline
\end{tabular}

$x$ No de positivos $\quad+\%$ de positivos $\quad x x$ Promedio de títulos

CUADRO No 18

Análisis por edad de los resultados de pruebas $\mathrm{HI}$ con 5 antígenos del grupo B practicadas con sueros de residentes de toda la vida en El Espinal. Zona Rural.

\begin{tabular}{|c|c|c|c|c|c|c|c|c|c|c|c|c|c|c|c|c|}
\hline \multirow{4}{*}{$\begin{array}{c}\begin{array}{c}\text { Edad en } \\
\text { años }\end{array} \\
<1\end{array}$} & \multirow{4}{*}{$\begin{array}{c}\begin{array}{c}\mathrm{N}^{9} \mathrm{de} \\
\text { personas } \\
\text { examinadas }\end{array} \\
5\end{array}$} & \multicolumn{6}{|c|}{ FIEBRE AMARILLA } & \multirow{2}{*}{\multicolumn{3}{|c|}{$\begin{array}{c}\text { ILHEUS } \\
\text { Cepa Laemmert }\end{array}$}} & \multirow{2}{*}{\multicolumn{3}{|c|}{$\frac{\text { DENGUE II }}{\text { Cepa Tr. } 1751}$}} & \multirow{2}{*}{\multicolumn{3}{|c|}{ ST. LOUIS }} \\
\hline & & \multicolumn{3}{|c|}{ Cepa $17 \mathrm{D}$} & \multicolumn{3}{|c|}{ Cepa JSS } & & & & & & & & & \\
\hline & & No P & $\% \mathrm{P}+$ & om. $x x$ & No $\mathrm{I}$ & $\% \mathrm{P}$. & Prom. & NoP. & $\% \mathrm{P}$. & rom. & No P. & $\% \mathrm{P}$. & rom. & No $P$. & $\% \mathrm{P}$. & rom. \\
\hline & & 0 & 0 & 0 & 0 & 0 & 0 & 1 & 20 & 2.0 & 1 & 20 & 1.0 & 3 & 60 & 1.3 \\
\hline $1-4$ & 8 & 1 & 13 & 3 & 1 & 13 & 0.5 & 1 & 13 & 2.0 & 0 & 0 & 0 & 2 & 25 & 2.5 \\
\hline $5-9$ & 11 & 3 & 27 & 2 & 2 & 18 & 2.5 & 8 & 73 & 2.8 & 7 & 64 & 2.6 & 8 & 73 & 2.1 \\
\hline $10-14$ & 9 & 5 & 56 & 1.4 & 4 & 45 & 2.0 & 6 & 67 & 3.6 & 6 & 67 & 3.1 & 7 & 78 & 3.1 \\
\hline $15-19$ & 10 & 4 & 40 & 2.8 & 4 & 40 & 3.0 & 9 & 90 & 3.3 & 5 & 50 & 2.5 & 9 & 90 & 3.6 \\
\hline $20-29$ & 5 & 3 & 60 & 3.3 & 3 & 60 & 2.3 & 4 & 80 & 4.7 & 3 & 60 & 6.0 & 4 & 80 & 4.5 \\
\hline $30+$ & 2 & 0 & 0 & 0 & 0 & 0 & 0 & 1 & 50 & 2 & 1 & 50 & 4.0 & 2 & 100 & 2.0 \\
\hline Total & 50 & 16 & 32 & 2.2 & 14 & 28 & 2.3 & 30 & 60 & 3.3 & 23 & 46 & 3.1 & 35 & 70 & 2.9 \\
\hline
\end{tabular}

$\times$ No de positivos $\quad+\%$ de positivos

$\mathbf{x x}$ Título promedio de las pruebas positivas 
CUADRO No 19

Espinal. Análisis de resultados de pruebas $\mathrm{HI}$ con antígenos de fiebre amarilla, Ilheus, Dengue y St. Louis en residentes de toda la vida. Proporción de sueros que reaccionaron con todos los antígenos (positivos cuádruples).

\begin{tabular}{|c|cc|cr||}
\hline \multirow{2}{*}{ Edad } & \multicolumn{2}{|c|}{ Zona Rural } & \multicolumn{2}{|c|}{ Zona Urbana } \\
& \multicolumn{2}{|c|}{$\mathbf{R}^{\mathbf{x}}$} & $\%$ & \multicolumn{2}{|c||}{$\mathbf{R}$} & $\%$ \\
\cline { 2 - 5 }$<1$ & $0 / 5$ & 0 & $0 / 3$ & 0 \\
$1-4$ & $0 / 8$ & 0 & $0 / 7$ & 0 \\
$5-9$ & $3 / 11$ & 27 & $1 / 11$ & 9 \\
$10-14$ & $5 / 9$ & 56 & $5 / 10$ & 50 \\
$15-19$ & $4 / 10$ & 40 & $6 / 7$ & 86 \\
$20-29$ & $3 / 5$ & 60 & $5 / 8$ & 63 \\
$30+$ & $0 / 2$ & 0 & $4 / 4$ & 100 \\
\hline Total & $15 / 50$ & 30 & $21 / 50$ & 42 \\
\hline
\end{tabular}

× Relación: № sueros positivos con todos los cuatro antígenos $\mathrm{N}$ ? de sueros examinados.

CUADRO No 20

Virus Dengue 2. Resultados de pruebas de neutralización en 327 personas residentes en el Alto Magdalena en áreas donde hasta en 1952 se registraba la presencia de Aedes aegypti. (Sueros recolectados en 1958).

\begin{tabular}{|c|c|c|c|c|c|c|}
\hline \multirow[b]{2}{*}{ Edad } & \multicolumn{2}{|c|}{ Hombres } & \multicolumn{2}{|c|}{ Mujeres } & \multicolumn{2}{|c|}{ Total } \\
\hline & $\mathrm{R}^{\mathrm{x}}$ & $\%$ & $\mathbf{R}$ & $\%$ & R & $\%$ \\
\hline$<1$ & $0 / 3$ & 0 & $0 / 5$ & 0 & $0 / 8$ & 0 \\
\hline $1-4$ & $1 / 8$ & 12.5 & $0 / 23$ & 0 & $1 / 31$ & 3.2 \\
\hline $5-9$ & $3 / 35$ & 8.6 & $3 / 24$ & 12.5 & $5 / 59$ & 8.5 \\
\hline $10-14$ & $11 / 70$ & 15.7 & $12 / 51$ & 25.5 & $24 / 121$ & 19.8 \\
\hline $15-19$ & $7 / 21$ & 33.3 & $9 / 36$ & 25.0 & $16 / 57$ & 28.1 \\
\hline $20-29$ & $3 / 9$ & 33.3 & $7 / 13$ & 53.8 & $10 / 22$ & 45.5 \\
\hline $30-39$ & $3 / 4$ & 75.0 & $1 / 3$ & 33.3 & $4 / 7$ & 57.1 \\
\hline $40-49$ & $4 / 8$ & 50.0 & $0 / 1$ & 0 & $4 / 9$ & 44.4 \\
\hline $50+$ & $5 / 6$ & 83.3 & $6 / 7$ & 85.7 & $11 / 13$ & 84.6 \\
\hline Total & $37 / 164$ & 22.6 & $39 / 163$ & 23.9 & $76 / 327$ & 23.3 \\
\hline
\end{tabular}

x No positivo / № examinado

CUADRO No 21

Valle del Magdalena Medio. Zona Rural de Barrancabermeja (fondo del valle). Resultado de pruebas de neutralización con virus Bussuq, e acuerdo con la edad y el sexo.

\begin{tabular}{|c|c|c|c|c|c|c|}
\hline \multirow{2}{*}{$\begin{array}{l}\text { Edad } \\
\text { (Años) }\end{array}$} & \multicolumn{2}{|l|}{ Hombres } & \multicolumn{2}{|c|}{ Mujeres } & \multicolumn{2}{|c|}{ Total } \\
\hline & $\mathrm{R}^{\mathrm{x}}$ & $\%$ & R & $\%$ & R & $\%$ \\
\hline $0-4$ & $2 / 11$ & 18 & $0 / 8$ & 0 & $2 / 19$ & 11 \\
\hline $5-9$ & $4 / 14$ & 29 & $2 / 10$ & 20 & $6 / 24$ & 25 \\
\hline $10-14$ & $0 / 11$ & 0 & $2 / 11$ & 18 & $2 / 22$ & 9 \\
\hline $15-19$ & $1 / 10$ & 10 & $3 / 10$ & 30 & $4 / 20$ & 20 \\
\hline $20-29$ & $3 / 10$ & 20 & $2 / 13$ & 15 & $4 / 23$ & 17 \\
\hline $30-39$ & $3 / 10$ & 30 & $5 / 10$ & 50 & $8 / 20$ & 40 \\
\hline $40-49$ & $3 / 11$ & 27 & $2 / 10$ & 20 & $5 / 21$ & 24 \\
\hline $50+$ & $4 / 8$ & 50 & $3 / 11$ & 27 & $7 / 19$ & 37 \\
\hline Total & $19 / 85$ & 22 & $19 / 83$ & 24 & $38 / 168$ & 23 \\
\hline
\end{tabular}

CUADRO N: 22

Valle del Magdalena Medio. Zona rural de Barrancabermeja (fondo del valle). Resultado de pruebas de neutralización con virus llheus, de acuerdo con la edad y el sexo.

\begin{tabular}{|c|c|c|c|c|c|c|}
\hline \multirow{2}{*}{$\begin{array}{c}\text { Edad } \\
\text { (Años) }\end{array}$} & \multicolumn{2}{|l|}{ Hombres } & \multicolumn{2}{|c|}{ Mujeres } & \multicolumn{2}{|c|}{ Total } \\
\hline & $R^{x}$ & $\%$ & $\mathbf{R}$ & $\%$ & $\mathbf{R}$ & $\%$ \\
\hline $0-4$ & $0 / 11$ & 0 & $0 / 8$ & 0 & $0 / 19$ & 0 \\
\hline $5-9$ & $0 / 9$ & 0 & $0 / 10$ & 0 & $0 / 19$ & 0 \\
\hline $10-14$ & $0 / 10$ & 0 & $0 / 10$ & 0 & $0 / 20$ & 0 \\
\hline $15-19$ & $0 / 9$ & 0 & $4 / 10$ & 40 & $4 / 19$ & 21 \\
\hline $20-29$ & $1 / 10$ & 10 & $1 / 12$ & 8 & $2 / 22$ & 9 \\
\hline $30-39$ & $3 / 10$ & 30 & $4 / 10$ & 40 & $7 / 20$ & 35 \\
\hline $40-49$ & $1 / 10$ & 10 & $1 / 10$ & 10 & $2 / 20$ & 10 \\
\hline $50+$ & $3 / 9$ & 33 & $1 / 10$ & 10 & $4 / 19$ & 21 \\
\hline Total & $8 / 78$ & 10 & $11 / 80$ & 13 & $19 / 158$ & 12 \\
\hline
\end{tabular}

$x$ № positivo / No examinado

CUADRO № 23

Virus Guaroa. Resultados de pruebas de neutralización en sueros tomados durante 1960 a adultos residentes en Guaroa y regiones vecinas, de acuerdo con el tiempo de residencia.

\begin{tabular}{|c|cc|}
\hline $\begin{array}{c}\text { Tiempo de } \\
\text { residencia } \\
\text { (Años) }\end{array}$ & Relación ${ }^{x}$ & $\%$ Pos. \\
\hline 1 & $4 / 8$ & 50 \\
2 & $5 / 10$ & 50 \\
3 & $11 / 20$ & 55 \\
4 & $3 / 6$ & 50 \\
5 & $5 / 8$ & 63 \\
$6-9$ & $2 / 4$ & 50 \\
$10-13$ & $7 / 9$ & 78 \\
$14+$ & $5 / 5$ & 100 \\
\hline \hline
\end{tabular}

x Número positivo / número examinado

CUADRO NQ 24

Virus Guaroa. Resultados de pruebas de neutralización practicadas a 53 personas residentes en la zona del fondo del Valle de San Vicente de Chucurí. Muestras tomadas en 1957.

\begin{tabular}{|c|c|c|c|c|c|c|}
\hline \multirow{2}{*}{$\begin{array}{c}\begin{array}{c}\text { Edad } \\
\text { (Años) }\end{array} \\
5-9 \\
10-14 \\
15-19 \\
20-29 \\
30-39 \\
40-49 \\
50+\end{array}$} & \multicolumn{2}{|c|}{$\begin{array}{c}\text { Hombres } \\
\text { Relación }{ }^{x} \% \text { Pos. }\end{array}$} & \multicolumn{2}{|c|}{$\begin{array}{c}\text { Mujeres } \\
\text { Relación } \% \text { Pos. }\end{array}$} & \multicolumn{2}{|c|}{$\begin{array}{c}\text { Total } \\
\text { Relación \% Pos. }\end{array}$} \\
\hline & \begin{tabular}{|c}
$3 / 6$ \\
$11 / 20$ \\
$1 / 2$ \\
$2 / 2$ \\
$2 / 2$ \\
$1 / 1$ \\
$4 / 4$
\end{tabular} & $\begin{array}{r}50 \\
55 \\
50 \\
100 \\
100 \\
100 \\
100\end{array}$ & $\begin{array}{l}1 / 1 \\
3 / 4 \\
3 / 5\end{array}$ & $\begin{array}{r}33 \\
67 \\
100 \\
75 \\
60\end{array}$ & $\begin{array}{c}4 / 9 \\
13 / 23 \\
1 / 2 \\
2 / 2 \\
5 / 6 \\
4 / 6 \\
4 / 4\end{array}$ & $\begin{array}{r}44 \\
57 \\
50 \\
100 \\
83 \\
67 \\
100\end{array}$ \\
\hline Totales & $24 / 37$ & 65 & $10 / 16$ & 63 & $34 / 53$ & 64 \\
\hline
\end{tabular}

x Número positivo / número examinado

x No positivo / No examinado

CUADRO NQ 25

Virus Guaroa. Pruebas de neutralización en sueros de personas residentes en el fondo del Valle, zona rural de Barrancabermeja, de acuerdo con la edad y el sexo.

\begin{tabular}{|c|c|c|c|c|c|c|}
\hline \multirow{3}{*}{$\begin{array}{c}\begin{array}{c}\text { Edad } \\
\text { (Años) }\end{array} \\
0-4 \\
5-9\end{array}$} & \multicolumn{2}{|c|}{$\begin{array}{c}\text { Hombres } \\
\text { Relación }{ }^{x} \% \text { Pos. }\end{array}$} & \multicolumn{2}{|c|}{$\begin{array}{c}\text { Mujeres } \\
\text { Relación \% Pos. }\end{array}$} & \multicolumn{2}{|c|}{$\begin{array}{c}\text { Total } \\
\text { Relación \% Pos. }\end{array}$} \\
\hline & $1 / 10$ & 10 & $1 / 8$ & 13 & $2 / 18$ & 11 \\
\hline & $2 / 8$ & 25 & $3 / 10$ & 30 & $5 / 18$ & 28 \\
\hline $10-14$ & $3 / 9$ & 33 & $3 / 10$ & 30 & $6 / 19$ & 32 \\
\hline $15-19$ & $1 / 9$ & 11 & $8 / 10$ & 80 & $9 / 19$ & 47 \\
\hline $20-29$ & $7 / 9$ & 78 & $5 / 12$ & 42 & $12 / 21$ & 57 \\
\hline $30-39$ & $7 / 10$ & 70 & $5 / 10$ & 50 & $12 / 20$ & 60 \\
\hline $40-49$ & $6 / 10$ & 60 & $8 / 10$ & 80 & $14 / 20$ & 70 \\
\hline $50+$ & $8 / 9$ & 89 & $5 / 10$ & 50 & $13 / 19$ & 68 \\
\hline Total & $35 / 74$ & 47 & $38 / 80$ & 48 & $73 / 154$ & 47 \\
\hline
\end{tabular}

x Relación: № positivo / № examinado 
CUADRO No 26

Virus Guaroa. Resultados de pruebas de neutralización practicadas en sueros de 731 personas residentes de distintas regiones de Colombia.

\begin{tabular}{|c|c|c|c|c|c|c|c|c|c|c|}
\hline \multirow{2}{*}{ Localidad } & \multirow{2}{*}{$\begin{array}{c}\text { Historia del virus Guaroa } \\
\text { en la localidad }\end{array}$} & \multirow{2}{*}{$\begin{array}{l}\text { Tiempo de } \\
\text { residencia } \\
\text { de los dadores }\end{array}$} & \multicolumn{7}{|c|}{ RESULTADOS } & \multirow{2}{*}{$\begin{array}{l}\text { Fecha de } \\
\text { sangría }\end{array}$} \\
\hline & & & Pos. & $\begin{array}{l}\text { meroxx } \\
\text { Inc. }\end{array}$ & Neg. & Total & Pos. & $\begin{array}{l}\text { orcentaj } \\
\text { Inc. }\end{array}$ & Neg. & \\
\hline $\begin{array}{l}\text { Guaroa } \\
\text { Guaroa } \\
\text { Chichimene }\end{array}$ & $\begin{array}{l}\text { Aislado simultáneamente con } \\
\text { los sueros para prueba NT }\end{array}$ & $\begin{array}{l}2-10 \text { meses } \\
\text { 2-6 meses } \\
\text { desconocida }\end{array}$ & $\begin{array}{l}34 \\
14 \\
10 \\
\end{array}$ & $\begin{array}{r}18 \\
8 \\
11 \\
\end{array}$ & $\begin{array}{r}17 \\
19 \\
8 \\
\end{array}$ & $\begin{array}{l}69 \\
41 \\
29 \\
\end{array}$ & $\begin{array}{l}49.3 \\
34.2 \\
34.5 \\
\end{array}$ & $\begin{array}{l}26.1 \\
19.5 \\
37.9 \\
\end{array}$ & $\begin{array}{l}24.6 \\
46.3 \\
27.6 \\
\end{array}$ & $\begin{array}{l}\text { Mayo } 1956 \\
\text { Mayo } 1956 \\
\text { Julio } 1958 \\
\end{array}$ \\
\hline $\begin{array}{l}\text { Guaroa } \\
\text { Guaroa } \\
\text { Guaroa } \\
\text { Guaroa } \\
\end{array}$ & $\begin{array}{l}\text { Aislado } 2 \text { años antes } \\
\text { Aislado } 2 \text { años antes } \\
\text { Aislado } 3 \text { años antes } \\
\text { Aislado } 41 / 2 \text { años antes }\end{array}$ & $\begin{array}{l}\text { "corto tiempo"x } \\
\text { desconocida } \\
1 \mathrm{~m} .-4 \text { años } \\
1-14 \text { años }\end{array}$ & $\begin{array}{r}0 \\
1 \\
6 \\
52 \\
\end{array}$ & $\begin{array}{r}2 \\
3 \\
10 \\
3\end{array}$ & $\begin{array}{r}32 \\
2 \\
2 \\
26\end{array}$ & $\begin{array}{r}34 \\
6 \\
18 \\
81 \\
\end{array}$ & $\begin{array}{c}0 \\
16.7 \\
33.3 \\
64.2\end{array}$ & $\begin{array}{r}6.2 \\
50.0 \\
55.6 \\
3.8\end{array}$ & $\begin{array}{l}93.8 \\
33.3 \\
11.1 \\
32.0\end{array}$ & $\begin{array}{l}\text { Julio } 1958 \\
\text { Julio } 1958 \\
\text { Julio } 1959 \\
\text { Dic. } 1960\end{array}$ \\
\hline $\begin{array}{l}\text { S. Vicente } \\
\text { valle } \\
\text { S. Vicente }\end{array}$ & $\begin{array}{l}\text { Virus no aislado de } 65.000 \\
\text { mosquitos inoculados }\end{array}$ & $\begin{array}{l}\text { desconocido } \\
5 \text { + años }\end{array}$ & $\begin{array}{l}73 \\
34 \\
\end{array}$ & $\begin{array}{l}16 \\
12 \\
\end{array}$ & $\begin{array}{r}65 \\
7 \\
\end{array}$ & $\begin{array}{r}154 \\
53 \\
\end{array}$ & $\begin{array}{l}47.4 \\
64.1 \\
\end{array}$ & $\begin{array}{l}10.4 \\
22.6 \\
\end{array}$ & $\begin{array}{l}42.2 \\
13.3 \\
\end{array}$ & $\begin{array}{l}\text { Junio } 1960 \\
\text { Abril } 1957\end{array}$ \\
\hline \multirow{2}{*}{$\begin{array}{l}\text { S. Vicente } \\
\text { estribación } \\
\text { Villeta } \\
\text { Espinal } \\
\text { Sibaté } \\
\text { Amanavén }\end{array}$} & \multirow[b]{2}{*}{$\begin{array}{l}\text { No se ha hecho intentos de } \\
\text { aislamiento de virus }\end{array}$} & toda la vida & 6 & 3 & 41 & 50 & 12.0 & 6.0 & 82.0 & Sept. 1956 \\
\hline & & $\begin{array}{l}\text { toda la vida o } \\
\text { casi toda la vida }\end{array}$ & $\begin{array}{l}1 \\
0 \\
0 \\
2\end{array}$ & $\begin{array}{l}0 \\
0 \\
0 \\
0\end{array}$ & $\begin{array}{r}78 \\
102 \\
10 \\
5\end{array}$ & $\begin{array}{r}79 \\
102 \\
10 \\
5\end{array}$ & $\begin{array}{l}1.3 \\
0 \\
0 \\
40.0\end{array}$ & $\begin{array}{l}0 \\
0 \\
0 \\
0\end{array}$ & $\begin{array}{r}98.7 \\
100.0 \\
100.0 \\
60.0\end{array}$ & $\begin{array}{ll}\text { Junio } & 1958 \\
\text { Junio } & 1958 \\
\text { Abril } & 1958 \\
\text { Julio } & 1958\end{array}$ \\
\hline
\end{tabular}

x La única información dice: "soldados muy recientemente llegados al lugar".

$\mathbf{x x}$ Pos. = Positivo Inc. = Inconcluyente Neg. = Negativo

CUADRO No 27

Resultado de pruebas serológicas practicadas a monos capturados en 1957 en tres localidades distintas de la zona del fondo del Valle en los municipios de San Vicente de Chucurí y de Barrancabermeja.

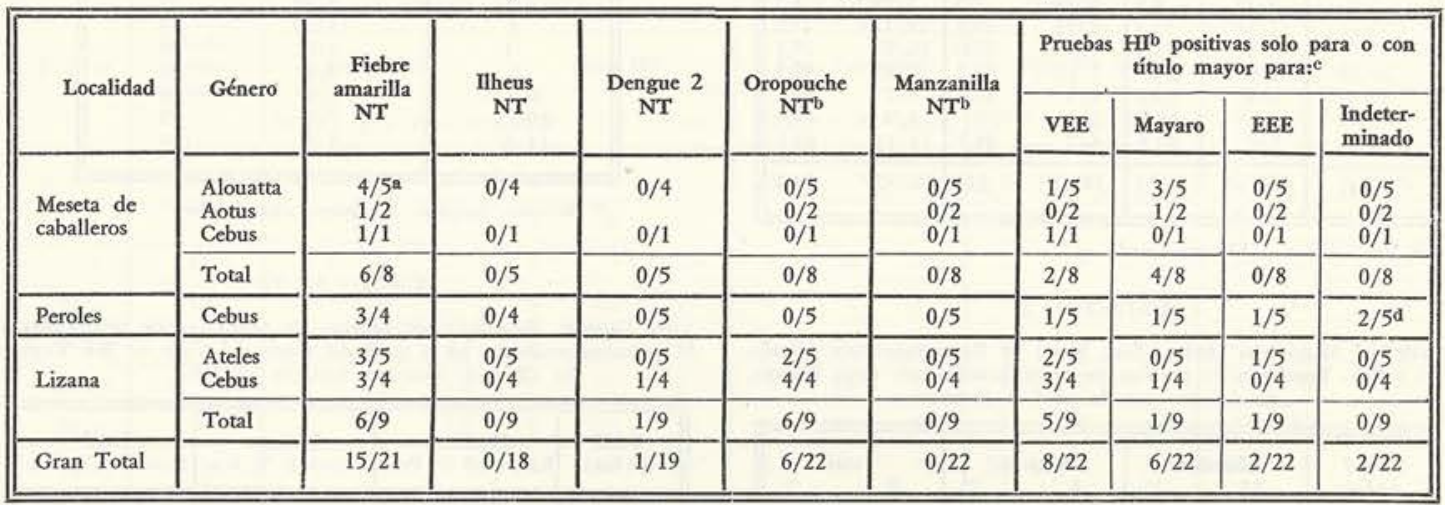

a No positivo / No examinados.

b Pruebas hechas en Trinidad Regional Virus Laboratory.

e Los sueros se probaron con antígenos de VEE, EEE, WEE y Mayaro.

d Los títulos de estos sueros fueron así: Suero 38491,3 con Mayaro y VEE; 2 con EEE y 1 con WEE. Suero 38493 , 3 con VEE, EEE y Mayaro; y 1 con WEE.

CUADRO No 28

Resultado de pruebas serológicas hechas a monos capturados en 1957 en los Llanos Orientales.

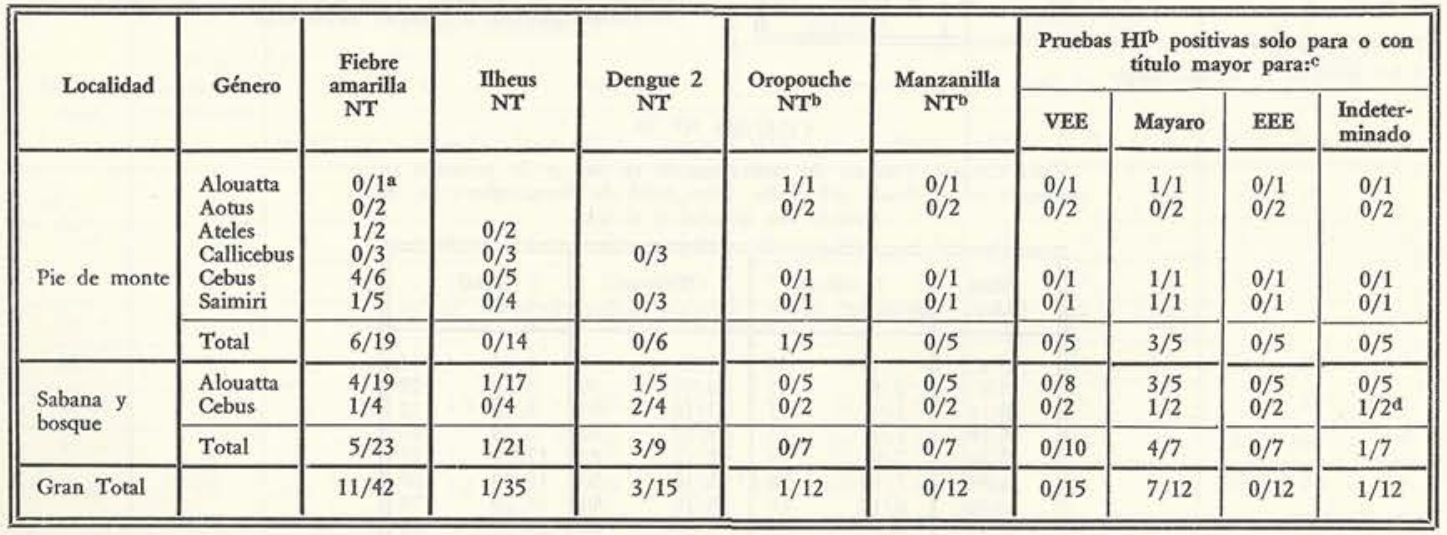

a № positivo /No examinados.

b Pruebas hechas en 'Trinidad Regional Virus Laboratory.

c Sueros: Los sueros se probaron con antígenos de VEE, FEE, WEE y Mayaro.

d Los títulos de estos sueros fueron así: Suero 38491,3 con Mayaro y VEE; 2 con EEE y 1 con WEE. Suero 38493 , 3 con VEE, EEE y Mayaro; y 1 con WEE. 
CUADRO No 29

Indices de neutralización (log.) de sueros inmunes anti-Mayaro y anti-43332 probados, tanto sin diluír como diluídos al 1/200, con virus Mayaro y con virus $43332^{\mathrm{a}}$

\begin{tabular}{|c|c|c|}
\hline Sueros $\sin$ diluír & Virus Mayaro & Virus 43332 \\
\hline Suero anti-Mayaro & $\geqslant 6.9$ & $\geqslant 4.0$ \\
\hline Suero anti-43332 & 3.3 & $\geqslant 4.2$ \\
\hline
\end{tabular}

\begin{tabular}{|c|c|c|}
\hline $\begin{array}{c}\text { Sueros diluídos } \\
\text { de } 1: 200^{\mathrm{b}}\end{array}$ & Virus Mayaro & Virus 43332 \\
\hline Suero anti-Mayaro & 5.9 & 1.4 \\
\hline Suero anti-43332 & 0.8 & 3.6 \\
\hline
\end{tabular}

a Este virus inicialmente se identificó como una cepa de Mayaro con base en la prueba de neutralización con sueros inmunes sin diluír (parte superior del Cuadro). Más tarde se notaron diferencias marcadas entre uno y otro, al hacerse las pruebas de neutralización con suero diluído al 1:200. Previamente el Dr. Max Theiler, en prucbas HI probó que el virus 43332 era una cepa de Una.

b Diluciones hechas con suero normal. Los mismos sueros se probaron en ambos experimentos.

\section{CUADRO No 30}

Resultado de pruebas NT con 6 virus en residentes de 4 lugares o "fracciones" de la zona del valle en las áreas rurales de los municipios de Barrancabermeja y San Vicente de Chucurí. (A estos sueros nos referimos en el texto como "sueros rurales de Barrancabermeja" obtenidos de personas sangradas en 1960).

\begin{tabular}{|c|c|c|c|c|c|c|c|c|c|c|c|c|}
\hline \multirow[b]{2}{*}{ Localidad $^{\mathrm{a}}$} & \multicolumn{2}{|c|}{ Guaroa } & \multicolumn{2}{|c|}{ Mayaro } & \multicolumn{2}{|c|}{ Bussuquara } & \multicolumn{2}{|c|}{ Ilheus } & \multicolumn{2}{|c|}{ St. Louis } & \multicolumn{2}{|c|}{ Dengue 2} \\
\hline & $\mathrm{R}+$ & $\% \mathrm{xx}$ & & $\%$ & & $\%$ & $\mathrm{R}$ & $\%$ & & $\%$ & $\mathbf{R}$ & $\%$ \\
\hline Peroles $b$ & $23 / 70$ & 77 & $14 / 29$ & 48 & $15 / 29$ & 52 & $7 / 30$ & 23 & $4 / 30$ & 13 & $1 / 29$ & 3 \\
\hline Tempestuosa ${ }^{c}$ & & & & & & & & & & & & \\
\hline $\begin{array}{l}\text { y Llana Fría } \\
\text { Taguales yc }\end{array}$ & $10 / 38$ & 26 & $11 / 37$ & 30 & $5 / 37$ & 14 & $3 / 38$ & 8 & $3 / 38$ & 5 & $3 / 38$ & 8 \\
\hline Llana Caliente & $9 / 23$ & 39 & $4 / 25$ & 16 & $6 / 27$ & 22 & $3 / 26$ & 12 & $0 / 26$ & 0 & $0 / 24$ & 0 \\
\hline $\begin{array}{l}\text { Yarima y } \\
\text { Clavellina }\end{array}$ & $31 / 63$ & 49 & $9 / 64$ & 14 & $12 / 75$ & 16 & $6 / 64$ & 9 & $3 / 64$ & 5 & $3 / 64$ & 5 \\
\hline
\end{tabular}

a En las 4 localidades la composición de los grupos estudiados según la edad y el sexo es similar. Por lo tanto los resultados son enteramente comparables.

Las cuatro localidades consideradas se encuentran todas dentro de un área aproximada de 200 kilómetros cuadrados.

En la figura $N^{\circ} 2$ se indican los lugares de Peroles donde se hicieron los aislamientos de virus.

Las tres localidades restantes se encuentran localizadas a una distancia no mayor de 20 kilómetros del sitio de Peroles, en línea recta.

b En Peroles se han aislado los siguientes virus: VEE, UNA, BUSSUQUARA, WYEOMYIA, ILHEUS. También se ha comprobado allí la existencia de fiebre amarilla. En este lugar se incluyen también sueros de "La Vizcaína", región contigua a Peroles.

c En estos lugares no se han hecho intentos de aislamiento de virus.

d En estos lugares se han intentado aislamientos de virus a partir de mosquitos, con resultados negativos.

$+\mathrm{R}=$ Relación: $\mathrm{N}^{\circ}$ positivo / $\mathrm{N}^{\circ}$ examinado. $\mathrm{xx} \%=$ Porcentaje de casos positivos. 